Mavi Atlas, 8(2)2020: 235-255

Makale Geliș | Received: 29.05.2020.

Makale Kabul| Accepted: 06.06.2020.

DOI: $10.18795 /$ gumusmaviatlas. 745162

Necdet AYSAL

Doç. Dr. Assoc.|Prof. Dr.

Ankara Üniversitesi, Türk İnk1lap Tarihi Enstitüsü, Ankara-TÜRKIYE Ankara University, Institute of Turkish Revolution History, Ankara-TURKEY

ORCID: 0000-0001-9574-6208 aysal@ankara.edu.tr

Hasan DİNÇER

Öğr. Gör. Dr.|T. Asst. Dr.

Ankara Üniversitesi, Türk İnkılap Tarihi Enstitüsü, Ankara-TÜRKIYE

Ankara University, The Institute of Turkish Revolution History, Ankara-TURKEY

ORCID: 0000-0002-4289-9953

hdincer@ankara.edu.tr

\title{
Türkiye’nin Sıhhî ve İçtimaî Coğrafyası Raporlarına Göre: Kırklareli
}

Öz

Osmanlı Devleti'nin Avrupa topraklarında Edirne vilayetine bağlı bir sancak merkezi olan Kırklareli, 19. yüzyıl resmî kayıtlarına göre dokuma, bağcılık ve hayvancılık ürünleri ile Avrupa pazarlarında revaçta olan bir şehirdir. Savaş yıllarında büyük bir göç akınına uğrayan kent, aynı zamanda 1920’de Yunan işgaline de maruz kalmıştır. İşgal yıllarında üretimde keskin bir düşüş yaşanmış özellikle Yunanlıların planlı yağmacıllŏı sonucu yoksulluk had safhaya ulaşmışıı. Kırklareli, Mudanya Ateşkes Antlaşması sonrası 10 Kasım 1922'de Yunan işgalinden kurtulmuştur. İsgal sonrası, halkın üretimi artırma gayreti ve devletin özellikle tarımı destekleme konusundaki çabasına karşın, savaşların yarattığı yıkım öylesine büyüktür ki, 1925 yılında dahi birçok alanda üretim miktarı 1894 yılının gerisindedir. Cumhuriyetin ilk yıllarında Kırklareli'de batıl inanç ve hurafeler halkın günlük yaşamında önemli yer tutmaktadır. Ancak eğitimin önemini çok erken kavrayan ve yeniliklere son derece açık olan şehir halkı, Cumhuriyetin bütün kazanımlarını coşkuyla sahiplenmiştir. Bugün itibarıyla Kırklareli'de yaşamakta olan gelenekler, zihniyet, dünyevî sorunları çözme usulleri ve üretim düzeyinin; 1920'li yılların verileri ve somut gerçekliği ile karşılaştırılması, kent halkının olduğu kadar Cumhuriyetin başarısını da değerlendirebilmeyi mümkün kılacaktır. 1922-1938 yılları arasında Türkiye'nin sosyal, kültürel, ekonomik ve sağlık konularındaki gerçekliğini ortaya koymak amacıyla hazırlanan raporlardan birisi de Kırklareli vilayetine aittir. Bu çalışmada, Kırklareli'nin Cumhuriyet Dönemi'ne devrolunan sosyal, kültürel ve iktisadi koşulları 1925 tarihli rapor çerçevesinde değerlendirilmiş ve şehrin Cumhuriyet Dönemi'nde kat ettiği gelişmeler tahlil edilmiştir.

Anahtar Kelimeler: Kırklareli, Cumhuriyet, Umur-1 Sıhhiye ve Muavenet-i İçtimâyye Vekâleti, Dr. Rıza Nur, Dr. Ahmed Hamdi.

\section{Kırklareli: In View of Turkey's Sanitary and Social Geography Report}

\section{Abstract}

Kırklareli, which was once a sanjak centre of the Ottoman Empire in the European territory of Edirne province, is a popular city in European markets with its weaving, viticulture and animal husbandry products according to the 19th century official records. The city, which was flooded in during the years of war, was also subjected to Greek occupation in 1920. There was a sharp decline in production during the occupation years, and especially as a result of planned looting of the Greeks, poverty reached peak levels. Kirklareli came through the Greek occupation on 10 November 1922 after the Mudanya Ceasefire Treaty. Despite the efforts of the people to increase production after the occupation and the state's efforts to support agriculture, the destruction caused by the wars was so great that the amount of production in many areas was behind 1894 levels even in 1925. During the initial years of the republic, superstitions and superstitious beliefs in Krrklareli had an important place in the daily life of the people. However, the people of the city, who grasped the importance of education very early and were extremely open to innovations, enthusiastically embraced all the achievements of the Republic. Comparing the traditions still living, mentality, methods of solving worldly problems and the level of production in Kurklareli today with the data and concrete 
reality of the 1920s will make it possible to evaluate the success of the Republic as well as the people of the city. One of the reports which were prepared in order to establish the reality about Turkey's social, cultural, economic and health issues between the years 1922 and 1938 also belongs to Kirklareli province. In this study, the social, cultural and economic conditions of Kurklareli transferred to the Republican period were evaluated within the framework of the report dated 1925 and the developments that the city made during the Republican period were analysed.

Keywords: Kirklareli, Republic, Ministry of Health, Ministry of Internal Affairs, Grand National Assembly of Turkey, Dr. Riza Nur, Dr. Ahmed Hamdi.

\section{Giriş}

Türk Ulusal Mücadelesi, "kurtuluş ve kuruluş" çalışmalarının iç içe geçtiği tarihsel bir süreçtir. Yurdu kurtarmaya dönük silahlı mücadele, yasama-yürütme yetkilerini uhdesinde toplayan TBMM'nin devletleşme yolundaki eylemleri ile eş zamanlı olarak yürütülmüştür. Olağanüstü şartlarda Ankara'da açılan TBMM, daha ilk günden itibaren yeni bir devlet kurmanın bütün gereklerini adım adım gerçekleştirmiştir. Bu çerçevede 25 Nisan’da altı kişilik Geçici İcra Heyeti, 3 Mayıs 1920’de 11 kişilik “Türkiye Büyük Millet Meclisi Hükümeti” kurulmuştur (TBMM Albümü, 2010: XVIII).

Meclis Hükümeti sistemi içerisinde Türk tarihinde ilk kez "Umur-1 Sihhiye ve Muavenet-i İçtimaîyye Vekâleti" adı ile Sağlık ve Sosyal Yardım Bakanlığı kurulmuştur (Şehsuvaroğlu ve Demirhan, 1984: 63). Savaşlar ve sağlık sorunları başta olmak üzere ekonomik-sosyal geriliğin toplumsal sonuçlarının saptanması ve bunlarla mücadele edilmesi amaciyla kurulan bakanlı̆ı̆n ele aldığı başlıca konular arasında, cehalet, fakirlikten kaynaklanan yetersiz beslenme ve bulaşıcı hastalıklarla mücadele gelmektedir (Türkiye'de Sihhat ve İçtimaî Muavenet Teşkilatının Cumhuriyet Devrindeki İnkişafi, 1937: 4-6). Bakanlık, yurt sathında gerçekleştireceği çalışmaların ülke gerçekleriyle uyumlu olması için 1921 yılında Türkiye'nin Sıhhi-i İçtimaî Coğrafyası adıyla bazı iller hakkında raporlar oluşturmak için bir çalışma başlatmıstır (Sayılır, 2013: 2). Sancak ve vilayetlerde görevli sıhhiye müdürleri ve doktorlar adı geçen raporları hazırlamaları için görevlendirilmiş ve 1922 yılında Sinop Sancağı hakkında ilk rapor hazırlanarak yayınlanmıştır. Adı geçen raporun sunuş yazısında Sağlık ve Sosyal Yardım Bakanı Dr. Rıza Nur, söz konusu çalışmanın Dr. Refik (Saydam) Bey'in bakanlığı döneminde başlatıldığını belirtmektedir (Mehmed Said, 1922: 2-3): “... Refik Beyefendi, ... Yurdumuzun sıhhî ve ictimaî tedkiki gibi mühîm bir nokta Vekâlet-i Muâvenet-i İctimâyye müdürü Doktor Muhyiddin Celal Bey tarafindan Vekâlete teklif olunarak sıhhiye müdürlerinden bu bâbda ma'lûmat taleb edilmiş, sıhhiye müdürleri tedkikât yaparak ..."

Akademik çalışmalara konu olan raporların toplam sayısı hakkında farklı görüşler mevcuttur: Koz (Koz, 1992: 39) on sekiz, Sayllır (Sayllır, 2013: 2) yirmi beş, Doğruöz (Doğruöz, 2011: 276) on sekiz, Gökçe-Yaprak (Gökçe ve Yaprak, 2012: 39) on dokuz, Gümüşçü (Gümüşçü, 1999: 944) on dokuz, Aysal-Arslan (Aysal ve Arslan, 2018: 425) yirmi bir rakamın kaydetmektedir. Tarafımızca basılmış ve ulaşılabilir durumda olan rapor sayısı yirmi olarak saptanmıştır: ${ }^{1}$ Bayezid, Sinop, Muğla (Menteşe), Çatalca, Kırkkilisa (Kırklareli), Gelibolu, Kengri (Çankırı), Kayseri, Gazi Ayıntab (Gaziantep), Kastamonu, Kırşehir, Urfa, Konya, Niğde, Tokat, Sivas, Hamidabad (Isparta), Erzurum, Ankara, Cebel-i Bereket (Osmaniye).

Kentler hakkındaki raporlarda bilgiler genellikle altı başlık altında sunulmuştur (Gümüşçü, 1999: 947):

Birinci kısım: Hudutlar, dağlar, nehirler, madenler, ormanlar, tarım ürünleri, hayvanlar, mülki taksimat; İkinci kısım: İklim, mevsimler, sıcaklık, yağışlar; Üçüncü kısım: Nüfus, giyim-kuşam, gelenekler; Dördüncü kısım: Sağllk kurumları mektep ve medreseler, oteller,

\footnotetext{
1 İstanbul için hazırlanmış monografi Milli Kütüphane kataloglarında gözükmekle birlikte, çalışanların samimi çabasına rağmen, söz konusu eser bulunamamıştır.
} 
hanlar, hamamlar, fabrikalar, kabristanlar, bataklıklar, içme suları; Beșinci kısım: Zührevi hastalıklar, bulaşıcı hastalıklar, salgınlar; Altıncı kısım: Doğum ve ölüm istatistikleri, sıtma ve frengi istatistik ve haritalar1

Cumhuriyetin yönetim, hukuk ve eğitim alanlarındaki radikal değişimlerinin iktisadî ve sosyal hayatı değiştirebilen atılımlarından önce gerçekleştiği malumdur. Dolayısıyla 1920’li yıllarda yayınlanan monografiler (Türkçe Sözlük, 2005: 1364)2 , muhtevasındaki bilgiler açısından Cumhuriyetin planlama ve uygulamalarını yönlendirici bir belge olmanın yanında, Osmanlıdan Cumhuriyete devrolan toplumu ekonomik, sosyal, kültürel ve sağlık cephelerinden tam bir gerçeklikle yansıtmaktadır. Monografilerde savaşların, geri kalmışlı̆̆ın, yoksulluğun, geleneklerin, hurafelerin halkın gündelik yaşamındaki yansımalarını bulmak mümkündür. Sağlık ve Sosyal Yardım Bakanlığı tarafından yayınlanan monografilerden birisi de Kırklareli Vilayeti hakkındadır. Kırklareli Sıhhiye ve Muavenet-i İctimaîye Müdürü Dr. Ahmed Hamdi Bey tarafindan hazırlanan ve "Türkiye Cumhuriyeti Sıhhiye ve Muavenet-i İctimaîye Vekâleti Neşriyatından" başlı̆̆ ile "Türkiye’nin Sıhhî-i İctimaî Coğrafyası Kırkkilisa 'Kırklarili Vilayeti”" adıyla İstanbul Kâğıtçlık ve Matbaacılık Anonim Şirketi tarafından 1925 (1341) yllında basılmıştır (Ahmed Hamdi, 1925: 145). ${ }^{3}$

Kırklareli vilayeti hakkında ele alınan iki monografi bulunmaktadır. Bu monografilerden biri, kısa alıntıları içeren genel bir kitap tanıtım yazısı şeklinde (Doğruöz, 2011: 275-284) ve diğeri ise kent halkının geleneksel şifa bulma yöntemlerini konu alan çalışmadır (Gökçe ve Yaprak, 2012: 39-42). Bu makalede, Dr. Ahmed Hamdi Bey tarafindan hazırlanan ve Osmanlica olarak basılan monografinin tamamı, Latin harflerine çevrilmiş ve sadeleştirilerek değerlendirilmiştir. Kırklareli'nin, Osmanlı Devleti'nin, son döneminde yaşadığı askerî başarısızlıklar, işgaller ve sosyal yıkımlardan daha çok etkilenmiş bir kent olduğu gerçeğinden hareketle; monografide yer verilen eğitim düzeyi, halk inanışları, üretim düzeyi/ürünleri, işgallerin muhtelif etkileri, halkın gündelik yaşamı/sorunları hakkındaki bilgilerden alıntılar yapılırken, bu olgular, tarihin değişim kadar devamlılığ1 da yansıttığı prensibinin kabulü gereği, geçmişin sonuçları olarak da tahlil edilecektir.

\section{Cumhuriyetin İlk Y1llarında Kırklareli}

Kırklareli 1361'de Osmanlı Devleti tarafından fethedilmiştir ${ }^{4}$ (Uzunçarşıll, 1994: 163). Osmanlı Dönemi'nde Kırkkilise olarak anılan şehir, Ayastefanos Antlaşması ile Bulgar Prensliği’ne bırakılmışsa da 1878 Berlin Anlaşması ile tekrar Osmanlı topraklarına dâhil edilmiştir. Şehir, 1854'te kaza durumuna getirilmiş ve 1879'da sancağa dönüştürülmüştür. 1890 y1l başlarında Edirne vilayetinin sancaklarından birisi olan Kırklareli, Birinci Balkan Savaşı'nda 30 Ekim 1912'de Bulgarlarca işgal edilmiş ve şehir İkinci Balkan Savaşı sonunda imzalanan İstanbul Antlaşması $^{5}$ ile 8 Temmuz 1913'te geri alınmıştır (Özbek, 2018: 104). Kırklareli Ulusal Bağımsızlık Savaşı yıllarında İngiliz ve Fransızların desteğini alan Yunanlılarca, 26 Temmuz 1920'de işgal edilmiştir. İşgal sırasında zor günler geçiren ve çok ağır baskılara maruz kalan yöre halkı, silahlı birlikler oluşturarak direnişe katılmış, Lüleburgaz Kongresi ile Ulusal Mücadele ile bütünleşme yolunda adımlar atmıştır. Bu arada Trakya'daki örgütlenmelerin Anadolu ve Rumeli Müdafaa-i

\footnotetext{
2 Monografi; tarih, coğrafya gibi alanlarda özel bir sorun üstüne yapılan inceleme şeklinde tanımlanmaktadır. Sağlık ve Sosyal Yardım Bakanlığı'nın amacı ve kentler hakkındaki bilgilerin toplandığı başlıklar göz önüne alındığında yazımızda monografi tabirinin kullanılması daha uygun düşecektir.

${ }^{3}$ Bkz., Ek-1.

4 Tarihi, Geç Kalkolitik Döneme kadar uzanan Kırklareli, Traklar (MÖ. 1200-513), Persler ve Odrisler (MÖ. 513359), Makedonya Krallı̆̆1 (MÖ. 359-334), İskender ve Diyadoklar (MÖ. 334-279), Galatlar (MÖ. 279-205), Bitinyalılar (MÖ. 205-74), Roma İmparatorluğu (MÖ. 74-MS 395) ve Bizans (395-1361) egemenliğinde kalmıştır. Bizans Dönemi'nde ise "Saranta Ek.klesies" (Kırk Kilise) adıyla anılmıştır.

51913 İstanbul Anlaşması ile Meriç Nehri sınır olarak kabul edilmiş ve Birinci Balkan Savaşı sonunda imzalanan Londra Antlaşması ile kaybedilen Edirne, Dimetoka ve Kırklareli yeniden Osmanlı topraklarına dâhil edilmiştir.
} 
Hukuk Cemiyeti'ne bağlı Trakya Müdafaa-i Hukuk Heyet-i Merkeziyesi'ne bağlanmaları kararlaştırılmıştır. Aynı zamanda TBMM'de Trakya'yı temsil etmek üzere üç kişi Edirne mebusu olarak seçilmiştir (Tanör, 2002: 154-291). Ulusal Bağımsızlık Savaşı, 11 Ekim 1922'de imzalanan Mudanya Ateşkes Antlaşması ile sona ermiştir. Antlaşma hükümlerine göre Yunanlılar Doğu Trakya'dan çekilecekler ve bölge İtilaf Devletleri aracilı̆̆yla Türk yönetimine devredilecekti. Bu bağlamda Mütarekenin 14/15 Ekim gecesi yürürlüğe girmesiyle Yunanlılar kentin işgalini sonlandırmış ve kenti Fransızlara teslim ederek bölgeden çekilmiştir. Fransızlar tarafindan 10 Kasım 1922'de Türk yönetimine teslim edilen Kurkkilise, 1924'te vilayet merkezi haline getirilmiş ve adı Kırklareli’ne dönüştürülmüştür (Akın, 1997: 9-11).

\section{Nüfus}

Kırklareli'nin 1925 yılı itibarıyla sahip olduğu nüfus, Osmanlı'nın Rumeli coğrafyasında 19. yüzyılın sonu ve 20. yüzyllın ilk çeyreğinde yaşanan siyasal gelişmelerin etkilerini yansıtmaktadır. 1877-1878 Osmanl1-Rus Savaşı'ndan sonra Balkanlardan Trakya ve Anadolu'ya yoğun göç yaşanmış, Kırklareli de bu gelişmelerden payını almıştır. 1893 yılı Edirne Vilayet Salnamesine göre Kırklareli Sancağının nüfusu 138.678'dir (Edirne Vilayeti Salnamesi, 1894: 493). 1905/1906 genel nüfus sayımında ise 181.204 olan toplam nüfusun 78.338'i İslam, 102.866's1 gayrimüslimdir (Karpat, 2010: 346-347).

Balkan Savaşı'ndan sonra 1913'te Bulgaristan ile yapılan anlaşma gereği, Trakya'da yaşayan yaklaşık 100.000 Bulgar Trakya'dan ayrılmıştır. Balkan Savaşları esnasında, yöredeki Rum Ortodoksların bir kısmı Yunanistan'a göç etmiş, Birinci Dünya Savaşı'ndan sonra bir bölümü geri dönmüş ve mübadele ile tamamı Yunanistan'a gönderilmiştir. 1919 yllında Kırklareli'nin nüfusu, 100.979 Türk, 21.611 Rum, 1.452 Bulgar olmak üzere toplam 124.042 olarak tespit edilmiştir (BCA., 1919: FK 272.0.0.12). Kurklareli'nin İslam nüfusundaki artış, Balkan Savaşları'nın kaybedilmesi ile ilgilidir. Zira 1912-1915 yılları arasında Balkanlardan göç eden Müslüman muhacirlerin yaklaşık üçte biri Edirne’ye yerleştirilmiştir ${ }^{6}$ (Arslan, 2008: 105-107).

Sağlık ve Sosyal Yardım Bakanlığı’nın 1925 tarihli monografisine göre Merkez, Babaeski, Lüleburgaz, Vize, Pınarhisar ve Demirköy kazalarından oluşan Kırklareli’nin nüfusu 79.896'dır. Nüfusun \% 97,3'ü İslâm, \% 0,83'ü Bulgar ve \% 1,2'si Musevî'dir. İslâmların \% 83,2'i Türk, \% 3,3’ü Arnavut, \% 2,1’i Boşnak ve \% 2,9’u Pomak'tır. Türk olmayan Müslüman gruplar hakkında şu açıklama mevcuttur (Türkiye'nin Sıhhi-i İctimaî Coğrafyası Kırkkilisa "Kırklarili" Vilayeti, 1925: 19-20):

... Pomakların bir kısmı mübadele tarikiyle vürud edenlerden, diğer kısm-1 azamı 1293 senesinde Babaeski kazasında iskân edilen kadim pomaklardan ibarettir. Arnavut ve Boşnaklar ile yüzde on nispetinde bir kısım Türkler dahi Balkan Harbi’ni müteakiben Rumeli'den hicret eyleyenler olup o zaman vilayet dâhilinde iskân edilmişlerdir. Mütebaki Türkler vilayetin as1l yerlileridir.

Şehirde İstanbul lehçesine yakın bir Türkçe konuşulduğu, Babaeski'de ise Pomakça konuşulduğu, hatta Pomaklar arasında Türkçe bilmeyenlerin bulunduğu ve köylülerin kasabalılara nazaran biraz kaba bir şive ile konuştukları ifade edilmektedir. 93 Harbi ve Balkan Savaşları toprak ve insan kayıpları ile sonuçlanırken, Trakya ve Anadolu'daki Türk nüfus yoğunluğu artmıştır. Daha önce dil alanında başlamıs olan Türkçülük, Balkan Savaşları sonrasında İttihat ve Terakki eliyle kapsamı genişletilerek devlet politikası olarak sürdürülmüş (Tunaya, 1989: 310-316), aynı yaklaşım (Toprak, 1995: 10-22) daha gelişkin biçimde Cumhuriyet döneminde de devam

\footnotetext{
${ }^{6}$ 1912-1915 yılları arasında gelen toplam 297.737 muhacirin 95.267’si ve 1915-1920 arası dönemde göç eden toplam 116.185 kişinin, 37.233’ü Edirne Vilayetinin sancaklarına (Kırklareli sancağı dâhil) yerleştirilmiştir.

${ }^{7}$ Bkz., Ek-2.
} 
ettirilmiştir ${ }^{8}$. Kırklareli'nde nüfus bağlamında Türkleşme, savaşlar ve anlaşmalar çerçevesinde gerçekleşmiştir.

\section{Sosyal ve Ekonomik Hayat \\ Tarim}

Osmanlı ve Cumhuriyet dönemleri resmî kayıtlarında Kırklareli’ndeki tarımsal faaliyetler hakkında somut bilgiler mevcuttur. 1894 Edirne Vilayet Salnamesi, 1913 Tarım Sayımı ${ }^{9}$ ve 1923 yılı verilerine göre Kırklareli’nde üretilen tarım ürünlerinin ton cinsinden miktarları şu şekildedir. 1894 Y1lı Vilayet Salnamesinde kızılca (buğday) 6.300, arpa 4.348, çavdar 2.216, üzüm 1.253, kuşyemi 757, misır 574, alaf (hayvan yemi) 553, keten 55, kenevir 12 ton olarak (Edirne Vilayeti Salnamesi, 1894: 269-273), 1913 Yılı Tarım Sayımında buğday 10.366, arpa 9.804, çavdar 3.414, üzüm 3.360, yulaf 2.971, misır 6.191, keten 595, soğan 423 ve keten 595 ton olarak gösterilmektedir (Güran, 1997: 93-139). 1923 yllı verilerinde ise buğday 5.620, tütün 533, arpa 4.550, çavdar 3.330, yulaf 2.360, kapluca 2.220, burçak 2.050, dar1 155, misir 4.032, susam 42, nohut 57, fasulye 53 ve mercimek 33 ton olarak verilmektedir (Türkiye'nin Sihhi-i İctimaî Coğrafyası Kırkkilisa “Kırklarili” Vilayeti, 1925: 7).

1925 tarihli monografide, Kırklareli’nde üretilen ürünlerin rakamsal değerleri çerçevesinde ilçeler tarıma elverişlilik açısından sınıflandırılmıştır. Babaeski'de hububat ve bakliyat, Büyükdere çevresinde sebze yetiştirilmektedir. Pınarhisar'da hububat ve bakliyatta bire on ürün alınmaktadır. $\mathrm{Bu}$ yörede çok rağbet gören buğday yetiştirilmektedir. Lüleburgaz, tarıma uygunsa da arazisinin yüzde sekseni meradır. İlçenin demiryolu güzergâhında yetiştirilen bostan mahsulü İstanbul'a satılmaktadır. Vize'nin, kuzeydoğusundaki arazi verimsizdir. İlçenin Sergen, Midye nahiyeleri baklagiller ve hububata müsait ise de halk kerestecilik ve kömürcülük ile geçinmektedir. Merkez ilçede hububat, bakliyat, çavdar, yüksek kalitede fasulye ve mercimek üretilmektedir. Demirköy, tarıma uygun değildir (Türkiye'nin Sıhhi-i İctimaî Coğrafyası Kırkkilisa "Kırklarili”" Vilayeti, 1925: $8-9)$.

Ekonomisi tarıma dayalı olan Kırklareli'nde hububat birinci sırayı almış, meyveciliğin tek gelişkin kolu bağcılik olmuştur. Balkan Savaşları'ndan önce en fakir ailenin bile üç dört dönüm bağı bulunmakta, ihtiyaçlarını pazar için ürettiği üzümün kazancıyla karşılamaya çalışmakta idi (Türkiye’nin Sıhhi-i İctimâ̂ Coğrafyası Kırkkilisa "Kırklarili” Vilayeti, 1925: 6): “... Mahsulatından rakı, şarap, konyak, hardaliye, pekmez, cevizli sucuk imal ve külliyetli miktarda İstanbul'a ve vilayât-1 saîreye ihraç edilmekte ve bu mahsulat oralarda fevkalâde rağbet görmekte idi." 1913 'te 3.360 ton üzümden yaklaşık 500 ton şarap ve 40 ton kadar rakı imal edilmiştir. Eski bir şarap diyarı olan Kırklareli’nin şarapları, Trakya'da makbul olmanın yanında 19. yüzyılda Fransa'ya da ihraç edilmektedir. Balkan Savaşları, Yunan işgali, muhaceretler ve filoksera hastalığ1 ${ }^{10}$ gibi sebeplerle harap olan bağlar (Gökbayrak, 2006: 37), 1925 y1lı itibarıly toplam 100.000-150.000 dönüme tekabül etmekte, yıllık 512-641 ton aras1 ürün alınmaktadır. Hâlbuki vaktiyle yıllık 1.500 tondan fazla şarap ihraç eden Kırklareli'nde, 1923'te ancak 128-200 ton civarında baş üzüm üretilebilmekte, kalanı ise Üsküp nahiyesinde yetiştirilmektedir (Türkiye'nin Sıhhi-i İctimaî Coğrafyası Kırkkilisa "Kırklarili" Vilayeti, 1925: 6-7): "Bağcılı̆̆ın zevalinden sonra çiftçilik halkın bilhassa vasıta-i intifa ve maişeti olmuştur." Monografide bağcıllı̆̆ geliştirme konusunda halkın kesinlikle devlet desteğine muhtaç olduğu vurgulanmaktadır.

\footnotetext{
8 Aydınların düşünceleri ve İttihat ve Terakki’nin politikalarında Türkçülüğün öne çıkmasında, Osmanlı Devleti’nin özellikle yirminci yüzyıl başlarında yaşadığı siyasal gelişmelerin ve kayıpların etkisi olmuştur.

9 1913’te Kırklareli Sancağı aşağı yukarı bugünkü Kırklareli ilinin topraklarını kapsamakta ve Merkez, Lüleburgaz, Babaeski, Vize, Demirköy ve Pınarhisar'dan oluşmaktadır.

10 Üzüm bağlarında görülen asma filizi biti veya asma uyuzu olarak bilinen bir hastalıktır. Toprakta yaşayan filoksera zararlısı, asma köklerini emerek beslendiğinden kökleri zarar gören asmaların gelişmesine olumsuz etki yapmaktadır.
} 
Tütün önceleri İnece ve Lüleburgaz'in bazı köylerinde üretilmektedir. Monografide, Selanik ve Drama'dan gelen muhacirlerin tütünü Kurklareli'nde yetiştirmelerinin yerli ahaliyi de heveslendirdiği, 1925 yılında ise yüksek rekolte beklendiği ve halkın refahının artacağına inanıldığ1 ifade edilmektedir. Vilayet içerisinde 1925 'de Alpullu Şeker Fabrikası'nın açılmasıyla tütün ve üzümün yerini şekerpancarı almış ve 1940'larda Bulgaristan'dan Türklerin gelmesiyle birlikte ayçiçeği ve mısır üretimi de yaygınlaşmıştır (Türkiye'nin Sıhhi-i İctimaî Coğrafyası Kırkkilisa "Kurklarili" Vilayeti, 1925: 8-9).

Vilayet genelinde arıcilığın ilkel usullerle yapıldığ ve eski sistem sepet kovanlarının kullanıldığı dile getirilmektedir. Bununla birlikte birkaç arıcının Amerikan sistemi kovan sandıkları kullanmaya başladığı, özellikle Merkez kaza, Demirköy, Pınarhisar çevresinin arıcılığa fevkalâde müsait olmakla birlikte desteklenmeye muhtaç oldukları zikredilmektedir (Türkiye'nin S1hhi-i İctimaî Coğrafyası Kırkkilisa "Kırklarili" Vilayeti, 1925: 10).

Şehrin orman yönünden zengin olmakla birlikte, yüzde sekseninin baltalık olup yalnız odun, kömür, tütün sırrğı imaline müsait olduğu belirtilmiştir (Türkiye'nin S1hhi-i İctimaî Coğrafyası Kırkkilisa "Kırklarili” Vilayeti, 1925: 4-5). Dereköy, Sazara, Beypınar, Çağlayık, Karadere ve Kofçaz ormanlarından çeşitli ziraat aletleri yapıldığı, Trakya'nın il ve ilçelerine satıldığ ifade edilmiştir. Ormancılık faaliyetleri açısından zengin potansiyelin, yatırım yapacak girişimci sınıf yokluğu sebebi ile çok fazla değerlendirilemediği de vurgulanmıştır. Yunan issgalinin Trakya'da her alanda yarattığı yıkıcı etki, ilin orman varlı̆̆1 için de geçerlidir. Yunanlıların, Merkez ve Pınarhisar kazalarında kuralsız aşırı kesim sonucu ormanları tamamen tahrip ettikleri belirtilmektedir (Türkiye'nin Sıhhi-i İctimaî Coğrafyası Kırkkilisa "Kırklarili" Vilayeti, 1925: 5): “... Yunan orman fen memurlar1, vilayet ormanlarını zengin emsalsiz buldukları istifade cihetini düşünerek Dereköy ve civarındaki ormanlardan mevcut servet-i haşebiyyenin yüzde yetmişi nispetinde travers keresteler imal ittirerek ahali-i mahâlliyeye angarya suretiyle ve şimendifer vâsıtasıyla son ricatleri zamanına kadar Yunanistan'a sevke devam itmişlerdir.”

Monografide ahalinin tarımsal faaliyetlerinde genellikle gelişmiş demir pulluklar kullandığı, kara sabanın pek az kullanıldığı belirtilmektedir. Bunun anlamı demir pullukların hayvanlarca çekildiğidir. Son yıllarda hükûmetçe gönderilen buharlı pulluk ve harman makinelerinin kullanıldığ1 belirtilmişse de, sayı verilmemiş olmasından bu modern araçların kayda değer miktarda olmadığına hükmedilebilir (Türkiye'nin Sıhhi-i İctimaî Coğrafyası Kırkkilisa "Kurklarili”" Vilayeti, 1925: 5-6). Alpullu Şeker Fabrikası'nın kuruluşu modern tarım araçları kullanımını arttırmışsa da, traktör kullanımı ancak 1950’lerden sonra yaygınlaşacaktır.

1927 yılı Türkiye sayımı verilerine bakıldığında Kırklareli’nde; üretilen tarım ürünleri ve yetiştirilen hayvan sayısında ciddi bir artışın olduğu ve ekonomisinin tarıma dayalı olma özelliğini sürdürdüğü görülmektedir. Zira nüfusun \% 79,3’ü tarımda; sanayi kollarındaki toplam 1.524 işçinin 1.196'sı ağaç ürünleri, dokuma ve tarıma dayalı sanayi alanlarında çalışmaktadır. 1932 yılında Teşvik-i Sanayi Kanunu'ndan yararlanan 13 işyerinden 10'u un fabrikasıdır (Yurt Ansiklopedisi, 1983: 4840-4841).

\section{Hayvanc1l1k}

Coğrafi yapısı hayvancilığa uygun olan Kırklareli’nin 1925 y1l öncesi sayımlarla tespit edilmiş hayvan varlığı hakkında şu bilgiler mevcuttur. 1894 Y1l Vilayet Salnamesinde 576.313 adet koyun, 175.943 keçi, 50.000 boğa-inek, 24.385 öküz, 7.346 manda, 8.710 beygir, 203 katır ve 30 eşek (Edirne Vilayet Salnamesi, 1894: 273-275); 1913 Y1lı Tarım Sayımında 103.896 koyun, 44.064 keçi, 23.264 sığır, 2.180 manda, 1.549 at, 2.201 katır ve 513 eşek görülmektedir (Güran, 1997: 140-147). 1923 yılı verileri dikkate alındığında 8.091 adet Koşum hayvanı (manda ve öküz), 671 koşum beygiri, 311 katır, 2.502 eşek, 22.515 inek (boğa, tosun, düve, buzağ1), 26.556 manda (boğa, malak), 1.044 at (aygır kısrak, tay), 141.791 koyun (koç, kuzu), 34.104 keçi (teke, oğlak) ve 90.750 adet kümes hayvanları (tavuk, hindi, kaz, ördek) yer almaktadır (Türkiye’nin Sıhhi-i İctimaî 
Coğrafyası Kırkkilisa “Kırklarili” Vilayeti, 1925: 13). Bu sayımlar karşılaştırıldığında 1894’ten 1913 yılına kadar artmış olması gereken hayvan varlığında bir düşüş görülmektedir. Bu azalışta en etkili unsurun Balkan Savaşları olduğu görülmektedir. Özellikle savaş sonunda Kırklareli’ndeki Bulgar nüfusun Türk nüfus ile değiş-tokuş edilmesi (Yıldırım, 2012: 80-81), savaş ortamından kaçan Türklerin İstanbul'a ulaşmak için inek ve manda arabalarını kullanmaları sayısal verilerde azalmalar söz konusu olmuştur (Arslan 2008: 95).

Birinci Dünya Savaşı, özellikle de 1920-22 dönemi Yunan işgali ve Mudanya Ateşkesi sonrasında Yunan ordusunun Trakya'dan çekilirken gerçekleştirdiği büyük çaplı, sistemli gasp ve hırsızlığın da Kırklareli hayvancılığı üzerinde yıkıcı bir etki yaptığı görülmektedir. Zira bazı hayvan gruplarına ait rakamlar 1913 yllı verilerinden bile düşüktür. Zor şartlara dayanıklılı̆̆1 düşünüldügünde manda ve eşek sayısındaki artışı, yoksulluğun yaygınlaşması olarak yorumlamak mümkündür. Hayvancıllk konusunda, yavaş da olsa iyileşme ancak 1923'ten sonra başlayacaktır.

Monografide bazı hayvanlar ve elde edilen ürünler hakkında ayrıntılı bilgiler de yer almaktadır. Bir koyundan yıllık 15.384 kg peynir üretilecek kadar süt alındığ1, tavukların senelik 150 yumurta verebildiği, atların ve ineklerin fiziksel özellikleri ve 1rkları, kümes hayvanlarının (kaz, ördek, hindi) ağırlıkları hakkında bilgiler mevcuttur ${ }^{11}$. Ancak elde edilen hayvansal ürünlerin il genelindeki toplam sayısal değeri verilmemiştir (Türkiye'nin Sihhi-i İctimaî Coğrafyası Kırkkilisa "Kırklarili" Vilayeti, 1925: 12).

\section{Sanayi ve Madencilik}

Kırklareli'nde 19. yüzyılda gelişkin sanayi dalı dokumacılıktır. Kent genelindeki 45 dokuma tezgâhında toplam 200 işçi çalışmakta ve yılda, 4.165 adet şayak ve fanila, 6.360 adet çul ve çuval üretilmektedir. Ayrıca kentte iki un fabrikasında 10.512 .400 ton un üretimi yapılmaktadır. Bunların yanı sıra şarap, yapağı, sadeyağ ve çeşitli peynirler Avrupa ülkelerine ve çevre illere satılmaktadır (Yurt Ansiklopedisi, 1983: 4815).

Kırklareli monografisinde, savaşlar ve nüfus kaybının etkisiyle tarıma dayalı sanayinin iyice gerilediği saptanmıştır (Türkiye’nin Sıhhi-i İctimaî Coğrafyası Kırkkilisa “Kırklarili”" Vilayeti, 1925: 22): "Memlekette sanayi pek çok geride kalmıştır. Daha doğrusu günden güne terakkisi lazım gelirken bilâkis düçâr-1 tedennî olmaktadır (aşağ1 düşmektedir)." Merkez kasabada kurtuluştan evvel üç un, bir buz, üç yapağ1 fabrikası olduğu, Yunanlıların çekilirken iki un ve iki yapağ1 fabrikasının donanımını götürdüğü, kalan un fabrikalarından birinin ise tarım aletleri fabrikasına dönüştürüldüğ̈̈, diğer un fabrikasının faaliyet hâlinde olduğu ayrıca vilayette 20 kadar da su değirmeninin bulunduğu bilgileri yer almaktadır. Monografiye göre Lüleburgaz'da elektrikli bir un fabrikası çalışır durumdadır. İçenin kuzey batısında gaz ile çalışan ancak tamire muhtaç ve çalışamaz hâlde bir un fabrikası ve köylerinde 18 kadar su değirmeni vardır. Vize, Pınarhisar ve Demirköyü'nde ise fabrikanın bulunmadığı, sadece su değirmenlerinin olduğu bilgisi vardır (Türkiye’nin Sıhhi-i İctimaî Coğrafyası Kırkkilisa “Kırklarili” Vilayeti, 1925: 36) ${ }^{12}$.

1925'te Alpullu Şeker Fabrikası'nın kuruluşu, kentin sanayi hayatı için çok önemli bir adım olmuş, tarımsal ürün farklılaşması ve fabrikada oluşturulan yapı sebebiyle işçiler aracıllı̆̆yla yeni kültürel alışkanlıkların toplumda yer etmesi gibi sonuçlar doğurmuştu. Monografi hazırlanırken fabrikanın kuruluş hazırlıkları devam ediyor olmalıdır ki monografide şeker fabrikası hakkında bilgi mevcut değildir. Kırklareli’nde birçok alandaki potansiyelin değerlendirilememe sebebi olarak sermayedar yokluğu vurgulansa da, Lüleburgaz'da 1929 yılında tüccar ve çiftlik sahipleri, Ziraat Bankası'nın kredi taleplerini karşılamada yetersiz kalması üzerine Lüleburgaz Birlik ve Ticaret

\footnotetext{
11 Adı geçen monografide kümes hayvanları için şu bilgiler verilmektedir: "Vilayet dâhilinde tavuk, horoz, hindi, kaz, ördek yetişir. Sıkletleri: Hindileri alelekser (çoğunlukla) 3,0 ila 6 kıyye kadar geliyor. Yerli cins kazlar 5-9 kilodur. Ördeklerin müteaddid nevleri (çeşitli türleri) yetişmekte olup 7-8 kilo gelenlere de tesadüf olunmaktadır.”.

12 Bkz., Ek-3.
} 
Bankası A.Ş.'yi kurabilmiştir. ${ }^{13}$ Adı geçen kurum, dönem içinde Trakya'da kurulmuş tek yerel bankadır (Bayer, 2020:1).

Kırklareli, 19. yüzyılda madencilik alanında pek fazla varlık gösterememiştir. Yalnızca Demirköy kazasında demir madenleri yüzyıllardır işletilmektedir. Bunların yanı sıra Tırnova'da bakır, gümüş ve kurşun madenleri tespit edilse de işletmeye açılamamıştır. Vilayet genelinde alçı ve lületaşı ocakları işler hâldedir. Lüleburgaz'in Sat1 Köyü’ndeki alçı madenleri ise ilgisizlikten körelmeye yüz tutmuştur. Monografide, ilin jeolojik özellikleri hakkında bir hayli bilgi mevcuttur (Türkiye’nin Sıhhi-i İctimaî Coğrafyası Kırkkilisa "Kırklarili" Vilayeti, 1925: 3): "Vilayet teşkilat-1 jeolojiye nokta-i nazarından arazî-i saniyeden olup merkez kaza ile Demirköy kazası jeoloji ve terkibât-1 arziyesi killi, şistli, marın tabakalarından müteşekkildir”. Merkez ilçe Dereköy nahiyesinde demir, kömür hatta damar hâlinde altın; Demirköyü'nde bakır, kömür, demir, pirit madeni bulunduğu belirtilmektedir. İyi cins demir madeninin ise bolca bulunduğu, Osmanlı döneminde tesis edilen demirhanenin 93 Harbi'nde Ruslarca tahrip edildiği ve kalıntılardan vaktiyle buranın bir yerleşim merkezi olduğu monografide dile getirilmektedir (Türkiye'nin Sıhhi-i İctimâ̂ Coğrafyası Kırkkilisa "Kırklarili" Vilayeti, 1925: 4): “... Elyevm duvarları, bir camiin harabesi, cesim-i çarhlar ve sahaları kaplayan cüruf-1 madeniye ve hatta cabeca göller meşhut olunur." Bunların yanı sıra 1912'de ilçede keşif yapan bir İngiliz şirketine 99 yılllğına maden imtiyazı verildiği, diğer ilçelerde maden ve il genelinde tuzla bulunmadığı bilgisi de yer almaktadır.

Kırklareli monografisinde Yunan işgalinin şehrin ekonomik hayatına yaptığı olumsuz etki hakkında bilgi verilse de bu yetersizdir. İşgalin, şehrin maddî varlığına etkisi araştırmalarda ele alınmıştır ki; Yunanlıların alıın, nakit para ve araç-gereç gasp etme, bina ve tarım-ulaşım araçlarını yakma/ tahrip etme konusundaki zararlarının dökümü mevcuttur. Yunanlılar, Kırklareli genelinde 14.829 altın, 274.575 adet evrak-1 nakdiye, 4.870.697 liralık devlete ait eşya, 5.826 ton hububat, 601.000 adet kereste ve araba tekerleği, 6.219 öküz arabas1, 2.701 manda, 14.327 öküz, 1.455 at, 1.570 eşeği gasp etmiş; 307 han-dükkân-mağaza ve 11 devlet binasını yakmış/tahrip etmiştir. Ayrıca 98 öldürme, 26 yaralama, 1.095 sürgün/esir etme, 1.054 darp/işkence ve namusa tecavüz suçu işlemişlerdir (Doğruöz, 2011: 201-205).

\section{Meslekler}

Kırklareli’nde 19. yüzyılda mesleklerin din gruplarına göre dağılımını gösteren araştırmalarda önemli bilgiler mevcuttur. Buna göre, kasap, attar (baharatçı), kürkçü, pabuççu, kiremitçi, çoban, bakkal, işçi, abacı, kuyumcu, dülger (marangöz), boyacı, arabacı, firınc1, çerçi, terzi, celeb (sığır tüccarı) olanların tamamı ya da büyük çoğunluğu Gayrimüslimdir. Berber ve bekçilerin tamamı Müslüman, derici ve hizmetkârlar ise hem Müslüman hem de Gayrimüslimlerden oluşmaktadır (Kabakc1, 2013: 64-74).

Monografide 1925 yllinda Kirklareli'nde icra edilen meslekler bahsi, savaşlar ve nüfus değişimleri ile beliren eksiklikleri yansıtmaktadır. Mevcut meslek dallarının şehrin ihtiyacına yetmediği; demirci, kuyumcu, marangoz, değirmenci, kasap, berber, ateşçi bulunduğu; doktor, avukat, eczacı, dişçi, nalbant, şişeci, sirkeci, saraç, saatçi, helvacı, bıçakçı, gibi sanatkârların ihtiyacı kısmen karşıladığı, dülger ve terzi bulunmadığ1 kaydedilmiştir. Başarıyla icra edilen alanlara da değinilmiştir (Türkiye'nin Sıhhi-i İctimaî Coğrafyası Kırkkilisa "Kırklarili" Vilayeti, 1925: 22): "Hâl-i hazırda ekseriyet-i âzimiyesi Türk olan vilayet dâhilinde yemenicilik ve kunduracılık sanatı Türklerde müterakki bir hâlde olup bu kabil sanatkârların mevcudu da çoktur." Bu bağlamda Türkler, Gayrimüslim unsurların gidişi ile oluşan boşluğu doldurmaya çalışmakta; doktorluk, eczacılık gibi uzun süreli eğitim; terzilik, dülgerlik gibi teknik bilgi gerektiren mesleklerde başarılı olabilmek uzun zamanı gerektirmektedir.

\footnotetext{
${ }^{13}$ Adı geçen banka, otuz beş yıl faaliyet göstermiş ve 1 Eylül 1964 tarihinde bankacılık faaliyetini sonlandırmıştır.
} 
Şehir halkının yeme-içme alıșkanlıklarına da monografide geniş yer verilmiştir. Köylü, savaşlardan önce yetiştirdiklerinin yaklaşık dörtte üçünü satmakta, kalanı da ihtiyaçlarına yetmekte iken yaşadığı ekonomik sıkıntılardan dolayı hâlihazırda yetiştirdiği ürün ve hayvanlarının tamamını pazarlarda satmak zorunda kalmaktadır (Türkiye'nin Sıhhi-i İctimaî Coğrafyası Kırkkilisa "Kurklarili" Vilayeti, 1925: 21): "Kuvve-i maliyesi müsait olan buğday unundan has ekmek, et ve yağlı yemekler fakir halk ve köylüler buğday ve ekseriyetle çavdar ile mahlût mısır ve yalnız mısır ve arpa unu ekmeği yerler, yemekler de kendi mahsulleri mercimek, fasulye tarhanadan ibarettir."

Yoksulluk o derecededir ki buğday ekmeği fakir evlerine nadiren girmekte, bulabilirlerse has ekmeği, karma undan yapılan ekmeğe katık yapmakta ve genellikle bir parça tuz ve bir soğanla beslenmektedirler (Doğruöz, 2005: 261-262). Özellikle köylerde bazı hane fertleri aylarca et yüzü görmemekte ve sonuçta sağlık sorunları yaşamaktadırlar (Türkiye'nin Sihhi-i İctimaî Coğrafyası Kurkkilisa "Kurklarili" Vilayeti, 1925: 22): “... Fukara kısmı kendilerine elzem olan mevâdd-1 gıdaiyeyi alamamak dolayısıyla sıhhat nokta-i nazarından pek düşkün bir hâlde bulunuyorlar." Günümüzde de Trakya köylerinde azla geçinmek anlamında "tuz soğan yemek" tabiri bir deyim olarak kullanılmaktadır.

\section{Ĕ̈itim}

Osmanlı Dönemi kayıtlarına göre 1892-1893 eğitim-öğretim yllında Kırklareli’nde Müslümanların 113 iptidaîsinde (ilkokulunda) 3.212 erkek ve 1.542 kız, toplam 4.754 öğrenci; Gayrimüslimlerin 85 iptidâ̂sinde ise 4.58 erkek ve 1.513 kız olmak üzere toplam 6.094 öğrenci eğitim görmektedir. Dönem içerisinde köylerin üçte ikisinde ilkokulun mevcut olduğu görülmektedir (Kanal, 2017: 114).

Kırklareli'nde ilk rüştiyenin (ortaokulun) 1870’te açıldığı kabul edilmektedir. 1898 y1lı itibarıyla Müslümanların Merkez kazadaki kız rüştiyesinde 71, Vize erkek rüştiyesinde 23, Babaeski erkek rüştiyesinde 27, Lüleburgaz erkek rüştiyesinde 44 olmak üzere toplam 94 öğrenci eğitim almaktadır. 1898-1900 yılları arasında Bulgar Ortodoksların Merkez kaza ve Tirnova'da birer erkek rüştiyesi ve toplam 118 öğrenci; Rumların Merkez kazada iki, Lüleburgaz, Babaeski ve Üsküp nahiyesinde birer olmak üzere toplam beş erkek rüştiyesi bulunmakta ve bunların toplam öğrenci sayıs1 328'dir (Tanilli, 1976: 14).

Kırklareli'nde ilk idadî (lise) 1892'de açılmıştır. Bu lisede 1895-1900 yılları arasında Müslüman öğrenciler çoğunlukta olup Gayrimüslim öğrencilerin oranı beşte bir düzeyindedir. Ayrıca bu lisede her yıl ortalama 102-122 öğrenci eğitim görmektedir. 1903 Maarif Salnamesine göre merkez kasaba ve Vize'de birer medrese ve bunların 14'er öğrencisi bulunmaktadır. Adı geçen monografide 1925 yılında vilayette medrese olmadığı da belirtilmiştir (Türkiye'nin Sihhi-i İctimaî Coğrafyası Kırkkilisa "Kurklarili” Vilayeti, 1925: 24-25). Osmanlı Devleti'ndeki genel uygulamaya uygun olarak Kırklareli'nde de her cemaatin bir meclisi vardı ve bu Meclisler okulların harcamalarını karşılamaktaydı ${ }^{14}$. Müslümanlarda ise bu görevi vakıflar üstlenmiştir. Köylerdeki iptidaî mekteplerinin öğretmen maaşı ve masrafları köylü tarafından ödenmektedir. Bu döneme dair ilginç saptamalardan birisi gayrimüslimlerin okul açmasına dair hukuksal kaidelerin pek titizlikle uygulanmamasıdır (Kanal, 2017: 130).

Okul ve öğrenci sayılarına bakıldığında Müslüman kesimin okul sayısının gayrimüslimlere k1yasla az olduğu düşünülebilirse de cemaatlerin toplam nüfus içindeki oranlar1 göz önüne alındığında mevcut tablonun normal olduğu açıktır. Balkan Savaşları öncesinden şehrin 1922 y1lında kurtuluşuna kadar geçen zaman aralığında merkez kasabada altı yılık erkek ve kız okulları, anaokulları, bir lise, çırak okulları ve gece kursları mevcuttur.

\footnotetext{
141886 tarihli Mekatib-i Gayrimüslime ve Ecnebiye Müfettişliği nizamnamesine göre altı ay içinde ruhsat almayan okullar kapatılacaktı. Ancak Merkez kazada 1880'de açılan Bulgar Ortodoks rüştiyesi 16, Tırnova'daki Bulgar Ortodoks rüştiyesi 18 yıl sonra ruhsat almıştır.
} 
Monografiye göre 1925 yılı itibarılyla Kırklareli’ndeki okul ve öğrenci sayıları hakkında şu bilgiler mevcuttur. Merkez kasaba 2 erkek, 2 kız, 11 karma, 1 ana mektebi; Babaeski 2 erkek, 2 kız, 5 karma; Lüleburgaz 1 erkek, 1 kız, 6 karma, 1 ana mektebi; Vize 1 erkek, 1 kız, 6 karma, 1 ana mektebi; Pınarhisar 2erkek, 2 kız, 9 karma; Demirköy'de ise 1 karma mektep vardır (Türkiye'nin Sıhhi-i İctimaî Coğrafyası Kırkkilisa "Kurklarili” Vilayeti, 1925: 33). Bununla birlikte vilayette eğitim konusunda özellikle müfredatın uygulanması ve nitelikli öğretmen temini konusunda sıkıntılar yaşandığı görülmektedir. Buna göre, Millî Eğitim Bakanlığı'nın belirlediği programlar kasabalarda büyük çapta uygulansa da köy okullarında mümkün olamamaktadır. Öğretmenlerin neredeyse yarısı Dârülmuâllim mezunu, diğerleri beş yıllık idadî veya sultanîyi bitirememiş kişilerden oluşmaktadır (Şimşek, 2014: 90-92). Ayrıca eğitim malzemesi yokluğu nedeniyle, mevcudu yetmiş seksen öğrenciyi bulan köy okullarında tek öğretmenin görevini tam yapmasının zorluğu vurgulanmıştır. Köy okulları ile ilgili diğer sorun; “... Çocukların mektebe devam mecburiyetinin hakkıyla tatbik edilememesidir. Bir köylü çocuğu kış mevsiminin ancak üç, dört ayını mektepte geçirir. Senenin mütebâkî günlerini çocuk köy işlerine hasr ider.” şeklinde ifade edilerek, bu sorunu çözecek düzenleme ihtiyacı belirtilmiştir (Türkiye'nin Sihhi-i İctimaî Coğrafyas1 Kırkkilisa "Kırklarili” Vilayeti, 1925: 33).

Vilayette eğitim konusundaki çabalara değinmeden önce savaşların ve eğitim alanındaki yenileşme adımlarının, okul tipleri konusunda toplum zihniyetinde yarattığı değişim hakkındaki tespitlere değinmek yerinde olacaktır. Buna göre, Balkan Savaşları ve Birinci Dünya Savaşı var olan medreselerin kapanmasına sebep olmuş, akabinde medrese eğitimine talep olmadığı için bunların canlandırılmasına gerek görülmemiştir (Türkiye'nin Sihhi-i İctimaî Coğrafyası Kırkkilisa "Kırklarili" Vilayeti, 1925: 35).

Maarifin ve usul-i cedîdeye muvafik tedrisatın terakkisini halkın mekteplerden aldığı zevkü neșe medrese tahsili arzusunu azaltmıștır. Medreselerde yalnız ulum-1 dinîye Kur'an okumaktan başka bir şey öğretilmez idi. Medrese talebesi arasında hatta isimlerini bile yazmaktan aciz bulunanlar vardı. Usul-i cedîd-i maarif azim bir inkılap hâsıl itmiş, halktaki medrese tahsili hevesine kuvvetli bir sedd ...

Ancak, bazı köylerin eğitimde hocaları tercih ettiği, sadece dinî kitaplara dayalı eğitimi istedikleri de belirtilmiştir. Ayrıca yakın zamanda din adamı azlığ1 sorunuyla karşılaşılacağı belirtilerek tedbir alınması gereği de vurgulanmıştır. Eğitime dair sorunlar yanında olumlu eğilim ve girişimlerin daha büyük olduğu söylenebilir. Zira ne zaman hizmete açılacakları belirtilmese de Merkez kasabada 17, Babaeski'de 16, Lüleburgaz'da 4, Vize'de 8, Pınarhisar'da 3, Demirköy'de 2 okulun inşa edileceği belirtilmektedir (Türkiye'nin Sıhhi-i İctimaî Coğrafyası Kırkkilisa "Kırklarili" Vilayeti, 1925: 33). Bu bilgilerden vilayette var olan okul sayısının neredeyse iki katına çıkarılması, kentin eğitime verdiği önemi açıkça ortaya koymaktadır. Monografide savaşların, göçlerin eğitimi sekteye uğrattığı, bununla birlikte halkın tutumunun bu konuda hızlı bir gelişmeyi mümkün kılacağ1 tespit edilmiştir (Türkiye'nin Sıhhi-i İctimâ̂ Coğrafyası Kurkkilisa "Kurklarili" Vilayeti, 1925: 24): “... Bu gün bütün halk maarifin klymet ve ulviyetini her şeye tercih itmekte ve bu hususta bütün varlığını göstermektedir. Diyebilirim ki yakılmış yıkılmış ve bütün yoksulluklar içinde çırpınmış olan on hanelik bir köy ahalisi, behemehâl bir gazeteye abone olmağı ve bunu kendi aralarında okumak ve anlamağı vazife edinmektedirler."

Dârülmuâllimin ve Dârülmuâllimata yirmi beş çocuğun öğretmen olmak üzere gönderilmiş olduğu belirtilmiştir ki bu Kırklareli halkının eğitim konusundaki eksiklikleri kendi gençleri ile çözmeye çalıştığı anlamına gelmektedir. Ayrıca İl Meclisi'nin 110.000 liralık gelirinin 70.000 liralık dilimini eğitim bütçesi olarak ayırmış olması, şehir yöneticilerinin bu konudaki samimi çabasını göstermektedir. Söz konusu çabaların geleceğe dair büyük ümitler yarattığ1 monografide ki cümlelerde somutlaşmaktadır (Türkiye'nin Sıhhi-i İctimâ̂ Coğrafyası Kırkkilisa 
“Kırklarili” Vilayeti, 1925: 25): “... Maarif hakkında kuvvet ve kudretle denilebilir ki Kırkkilise maarif hususunda Trakya vilayetleri arasında birinci dereceyi ihraz edebilecektir."

\section{Hastalıklar-Sağlık Kurumları}

Sağlık, Cumhuriyet yönetiminin geçmişten devraldığı en sorunlu alanlardan birisidir (Türkiye'de Sıhhat ve İçtimai Muavenet Teşkilatı'nın Cumhuriyet Devrindeki İnkişafı 1937: 5): "Sitma şehirleri, köyleri mezarlı̆̆a çevirmiş, ... Frengi, trahom... Gelecek neslin bile keyfiyet ve kemiyetine tesir edecek meşum akıbetler doğuruyordu. Umumi sefalet, kültür düşkünlüğü... çocuk bakımsızlığ .... gibi dertler yurttaşlar arasında tahribat yapmaya sebep oluyordu.” Kırklareli monografisinde Midye ve İğneada köylerinde salgın bir halde sıtma, mide, cilt ve göz, kış mevsiminde ise grip, akciğer, zatürree ve eklem romatizması gibi hastalıkların görüldügü̈ köylerde kasık fitığının yaygın olduğu belirtilmektedir (Türkiye'nin Sıhhi-i İctimâ̂ Coğrafyası Kırkkilisa "Kurklarili" Vilayeti, 1925: 33). ${ }^{15}$

Monografide, Balkan Harbi’nden önce binde bir oranında iken, Birinci Dünya Savaşı ve sebep olduğu yoksulluk ve geçim darlığının fuhuşu arttırdığı, zührevî hastalıkların yayılmaması için merkez kasabada resmen bir umumhane açıldığı, kontrollerin yapıldığı ve zaman zaman belsoğukluğu vakasına rastlandığı ifade edilmektedir. Binde yarım oranında frengiye tesadüf olunduğu, vakalara hızla müdahale edildiği, zabita kuvvetinin olmaması sebebiyle frengiye ekseriyetle köylerde rastlandığ1 dile getirilmektedir (Tekir, 2019: 408-413). Bu arada frengi hakkında halkın bilgisiz olduğu ve hastanın doktora gitmek istemediği, yakınlarının da kendilerince tedavi uyguladığı görülmektedir (Türkiye'nin Sıhhi-i İctimaî Coğrafyası Kırkkilisa "Kırklarili" Vilayeti, 1925: 41-43):

... Bir hastanın yavaş yavaş başlayarak sesi kısılmış, evvelce öksürügü ve sair araz-1 dereniyesi de mevcut imiş. Hastayı üç beş gün kadar aç birakmakla beraber cıva tütsüsüne koymuşlar, hastanın bütün dişleri, lisatı (diş etleri) ve dili harabiyet kesb itmiş, hasta karnı aç olduğu hâlde hiçbir şey yiyememeye başlamıştır. Boğazındaki tezahürat daha ziyade ilerlemiş olduğu hâlde akrabası hekime müracaat ittirmemişlerdi. Bu garip vakada hastadaki larenjit tüberkülozun frengi diye tedavisine kalkışılmışıı...

Midye ve İğneada nahiyelerinde bataklıklar olduğundan civar halkın nerdeyse hepsi sitmalıdır (Yavuz, 2018: 649-650). Dişarıdan ticari sebeplerle gelenler de sitmaya tutulmaktadır. Hastalık kinin ve arsenik ile tedavi edilmeye çalışılmaktadır. Kırklareli'nin iklimi soğuk olduğundan verem vakasına nadiren rastlanmaktadır. 1922-1924 yılları arasında vilayette 5 çiçek vakasının görüldüğü ve bu hastalığın Makedonya civarından gelen muhacirlerden bulaştığı, difteriye ise hiç rastlanmadığı ifade edilmektedir (Türkiye'nin Sıhhi-i İctimaî Coğrafyası Kırkkilisa "Kurklarili" Vilayeti, 1925: 42-43). Yine bu y1llar arasinda on iki lekeli humma, bir humma-y1 nifasi, otuz bir kızamık, kırk beş boğmaca, dört grip vakası zuhur etmiştir. Bu arada on iki lekeli hummadan iki vefat söz konusu olmuştur. Lekenin bulaşma kaynağı olarak Selanik görülmektedir. Zira Yunanlılar Trakya'yı tahliye ederken esir aldıkları kişileri Selanik'e, Dedeağaç'a, Semadirek Adası'na götürmüşlerdir. Bu kişiler perişan bir halde dönmüşler ve lekeli hummayı Trakya'ya getirmişlerdir. Humma-yı nifasi ve kızamık da Selanik ve Drama'dan muhacirlerce getirilmiştir. Grip ve boğmaca yerliler ve muhacirler arasında görülmektedir. Boğmacadan beş, kızamıktan üç vefat gerçekleşmiştir. 1910'da yapılan tatbikat günlerinde Lüleburgaz'da asker arasında kolera vuku bulmuş ve yüze yakın vefat gerçekleşmiştir. O tarihten sonra kolera ve benzer hastalıklar vilayette görülmemiştir. Merkez Sihhiye Dairesi'ne göre vilayette 1923 yllında 855 doğum ve 718 vefat olmuştur. Toplam nüfusa göre vefat \% 2,3 ve çocuklarda \% 0,1'dir (Türkiye'de Sihhat ve İçtimai Muavenet Teşkilatı'nın Cumhuriyet Devrindeki İnkişafı, 1937: 8). Çocuk ölümlerinde

\footnotetext{
15 Bkz., Ek-4.
} 
yaygın sebepler, doğumdan iki yaşa kadar olan evrede bakımsızlık ve ishalden kaynaklanmıştır. Valiliğin çabasına rağmen nahiye ve köylerden sağlıklı nüfus bilgisi alınamamaktadır. Vilayette 1920-1922 y1llarına ait yalnız tapu ve kısmen vergi dairesi kayıtları mevcuttur. Bununla birlikte vilayete ilişkin pek çok resmi kayıt, işgal yıllarında Yunanlılar tarafindan imha edilmiştir (Türkiye'nin Sıhhi-i İctimaî Coğrafyası Kırkkilisa "Kırklarili” Vilayeti, 1925: 44-45). ${ }^{16}$

Şehirlerde yaşayan insanların, eğitim ve aile terbiyesinin sonucu olarak temizliğe özen gösterdikleri ancak köylerde kahvehanelerin, evlerin yakınlarında bulunan gübre ve çöp birikintilerinin yaydığ1 kötü kokunun, çeşitli hastalıklanı beraberinde getirdiği ifade edilmiştir. $\mathrm{Bu}$ durum sıhhiye memurlarının almış olduğu bir takım önlemlerle çözülmeye başlamıştır. İlçelerde tuvaletlerin muntazam olduğu ancak köylerde ve Çöplüce deresi civarındaki hanelerde, derenin taşkın suyunun atıklar için kullanıldığ1 belirtilmiştir. Diğer semtlerde ise atıklar için çukurlar kullanılmaktadır (Türkiye'nin Sıhhi-i İctimaî Coğrafyası Kırkkilisa "Kırklarili" Vilayeti, 1925: 39): "Köylerde çukur da yoktur. Köy evlerinin bahçeleri, havlusu, zemin katı hülasa her tarafı köylü tarafindan hela ittihaz olunabiliyor. Bu gibilerce def-i hacet hissi nerede zuhur eder ise orada tatmin edilir. " Bu sebeple açılan çukurların çevreye aşırı bir koku yaydığı vurgulanmıştır.

Kırklareli'nin muhtelif yerlerinde bataklılar olduğu; sivrisinek, dolayısıyla sitmanın buralardan yayıldığı, sitma ve sitmadan kaynaklanan dalak büyümesi neticesinde hayli ölümler olduğu kaydedilmiştir (Türkiye'nin Sıhhi-i İctimaî Coğrafyası Kırkkilisa "Kırklarili”" Vilayeti, 1925: 40-41 $)^{17}$. İlçelerin içme suyu ihtiyacının membalardan, çeşmelere getirilerek karşılandığı belirtilmiştir. Merkez kasabadaki "Babapınan" membaının, geçmişte askeriyece yapılan motorlu taşıma sisteminin işgal günlerinde Yunan askerlerince tahrip edildiği, kurtuluştan sonra tamir edildiği bilgisi mevcuttur. Vilayette hemen her evde, kuyu ve sarnıç bulunmaktadır. Pınarhisar ve Vize'deki zengin kaynak suları, içme ve tarımsal sulamaya yeter durumdadır. Babaeski, Demirköy'ünde kuyu ve memba suları; ova köylerinde kuyu ve orman köylerinde ise memba, dere suları içim amaçlı kullanılmaktadır (Türkiye'nin Sıhhi-i İctimaî Coğrafyası Kırkkilisa "Kırklarili" Vilayeti, 1925: 31).

Monografide kentteki sağlık kurumları hakkında bilgiler de mevcuttur. 1924 y1lında Lüleburgaz ve Demirköy kazalarında beşer yataklı birer muayene ve tedavi evi yapıldığı, Merkez kasabada yirmi beş yataklı, iki doktorlu bir hastane olduğu ancak ameliyat yapılamadığ1 ve tıbbi malzeme eksikliği olduğu anlaşılmaktadır (Türkiye'nin Sıhhi-i İctimaî Coğrafyası Kırkkilisa “Kırklarili” Vilayeti, 1925: 41): “... Memleket hasta hanesi namına hediye edilen mikroskobu ile ufak ufak bir laboratuvar tesis edilerek vekâyi-i müstacele hâll idilmekdedir (acil olaylara müdahale edilmektedir)."

Vilayette belediyeye ait Belediye Eczanesi, şahıslara ait Merkez Eczanesi ve Şevket Osman Eczanesi bulunmaktadır. Pınarhisar'da Çorun-zade Mustafa Arif Efendi'ye ait olan eczane, sahibi askere gittiğinden kapalıdır. Eczanelerde halkın ihtiyacını karşılayacak miktarda ilaç mevcuttur. Vize, Babaeski, Pınarhisar kazalarında birer dispanser mevcuttur. Pinarhisar dispanseri tam hizmet veriyorsa da diğerleri tamire muhtaç ve malzeme eksikliği sebebiyle açık değildir. Monografide, Kırklareli’nin ayrı bir il olmasından sonra dispanserler ile ilgili düzenlemelerin layıkıyla yapılamadığı vurgulanmıştır. Dispanserler için 1925 yılı Özel İdare bütçesinden 480 liralık ödenek ayrılmakla birlikte bunun yetersiz olduğu vurgulanmıştır. Ayrıca, sağlık personelinin yetersiz olduğu belirtilirken ilaç ve sağlık malzemelerinin İstanbul Sihhiye Müdüriyetinden temin edildiği açıklanmıştır. Vilayette halkın tıbba güvensiz olduğu, monografideki önemli tespitlerdendir. Bunun öncelikli sebebinin yaygın olarak rastlanan üfürükçülerdir. Çeşitli

\footnotetext{
161925 tarihli Kırklareli haritası için bkz., Ek-5.

17 Vize kazası ve Midye nahiyesinden geçen derelerin denize ulaştıkları yerde, İğneada nahiyesinin denize yakın alanlarında, Vize kazasının Aksicim köyü yakınında, Vize ile Saray kazaları arasındaki bir sahada bataklıklar bulunmaktadır.
} 
örneklerde halkın modern tıbbı son çare olarak gördüğ̈ saptanmıştır (Türkiye'nin Sıhhi-i İctimaî Coğrafyas1 Kırkkilisa "Kırklarili” Vilayeti, 1925: 41):

... Halktan birinin başı ağrıdığı zaman tabibe müracaat etmeyip hevâcelere (hocalara) üfürükçülere giderek okuturlar ve bu okumakla iyi olmağa çalışırlar. Sarılık olduğu zaman derhâl berbere koşarlar dilinin altından kan aldırırlar, ustura ile iki üç yerinden çizdirirler, şifa bulmadıkları zaman hekime müracaat ederler. İsabet-i ayna 'büyüye sihre' cin çarpmasına itikatlanı olduğu gibi ateşli olan bir hastanın derece-i hararetinden sayıkladığı zaman 'kim bilir ne tarafa su dökmüştür' diye hemen hevâceyi davet ederler.

Benzer örneklerin çokluğuna karşın eğitimin yaygınlaşması ve doktorların çalışmaları ile halkın hurafelerden uzaklaştı̆̆ belirtilmiştir. Hükûmet de bu konuda takdire değer bir ciddiyetle çalışmaktadır. Monografide Balkan Savaşları, Cihan Harbi ve Yunan işgali ile gerçekleşen yoksulluğun Kırklareli halkının fiziksel yapısında yarattığı değişime de yer verilmiştir (Türkiye'nin Sıhhi-i İctimaî Coğrafyası Kırkkilisa "Kırklarili" Vilayeti, 1925: 30): "Eskiden kalma güçlü, nesil zevale yüz tutmaktadır ki esbabı arasında fakr ve sefalet, nezafete âdem-i riayet, bedenî terbiyeye âdem-i rağbet şayan-dikkatdir. Halkın birçoğu muhtaç olduğu mevâdd-1 gıdaiyeyi tedarikte izhâr-1 acz itmekde olduğu küul ibtilâsının (alkol düşkünlügüu) vesâir suî-istimalâtın eseridir."

Geçmişte yaygin olan güreş, kalkan, cirit, at yarışı gibi halk sağlığına katkı yapan sporların giderek azalmasının da halkın bünyece zayıflığının sebeplerinden olduğu vurgulanmıştır. Şehrin kurtuluşundan sonra halkın spora ilgisinde artış olduğu belirtilerek bir takım öneriler sunulmuştur (Türkiye'nin Sıhhi-i İctimaî Coğrafyası Kurkkilisa "Kurklarili”" Vilayeti, 1925: 28-29). Spor okullarla sınırlanmamalı, uygun yerlerde spor salonları açılmalı, gelecek nesilleri fiziken güçlendirmek için binicilik, güreş ve diğer kolların desteklenmesi gerekliliğine vurgu yapılmıştır.

\section{Gelenekler}

Osmanlı'dan Cumhuriyet'e iktisaden geri, dünyevi sorunların bilimsel yollarla çözülemediği bir toplumsal yapı devrolmuştur. Yirminci yüzyıl başlarındaki Türk halk kültürü üzerine yapılan araştırmalar batıl inanç, hurafelerin toplum hayatındaki yaygınlı̆̆ı, çeşitli istekler, özellikle de hastalıklara çare olacağı düşüncesiyle türbelerin ziyaret edilme gerçeğini işaret etmektedir (Boratav, 1973: 40-45). Bu olgunun Kurklareli için de geçerli olduğu anlaşılmaktadır. Kırklareli halkının şeytan, peri, cin gibi şeylere inandıkları, türbe ve tekkelere de son derece rağbet ettikleri kaydedilmiştir. Monografide türbeler ve umulan çarelere bakıldığında, türbeler arası bir işbölümü de göze çarpmaktadır (Türkiye'nin Sıhhi-i İctimaî Coğrafyası Kırkkilisa "Kırklarili" Vilayeti, 1925: 25-26):

... Kırklar ve Çömlek Baba buraya kırk günlük çocuğu hastalandığ1 zaman getirirler, bir çömlek suyu türbelerin üzerine dökerek şifa taleb ederler. Merkeze tabi İnece nahiyesi civarında üç buçuk saat mesafede "Ariz baba" türbesi mevcuttur. Hasta olanlar neyl-i şifâ içün buraya gelirler.

Pınarhisar dâhilinde 'Bin bir Oklu Ahmet Baba' hastanın ayakları tutmadığı zaman ayaklarını türbe sandukasının içine idhâl ederek bir müddet tutarlar, kurban zebh ederek Kur'an tilâvet ederler. Bilhassa bu Ahmet Babaya Kaza ve civar ahalisinin pek ziyade hürmet ve itikatları vardır. Halk dini günlerde Cuma ve Pazar geceleri bu türbelerde mum yakmakta, ecdat mezarları başında Kur'an okumaktadırlar.

... Kırkkilise'nin şimal-i şarkîsinde Balaban Baba vardır, etraf-1 erbaası badem ve ceviz ağaçlarıyla muhat, çemen zar bir mesiredir. İlkbahar mevsiminde bütün Kırkkilise ahalisi öğleden sonra buraya giderek teferrüç ederler. Akşama kadar eğlenirler, türbeyi mumlarla tenvir ederek avdet ederler. Hızır Baba ve Mahya Baba Türbeleri de gezinti ve ziyaret mahalleridir. Halk bunlara pek ziyade hürmet ve riayet ederler ve bu zatlar1 Kırkkilise'nin ve civarının fâtihi add ederler. 
Monografide Kırklareli’ndeki diğer geleneklere de yer verilmiştir. Evliliklerin görücü usulü ile yapıldığ1 vurgulanmış, söz kesme ve düğün ile ilgili kız ve erkek tarafına düssen görevler, hediyeler, dügün günlerindeki eğlenceler, çeyiz serme ve takılar hakkında aynnntılı bilgiler verilmiştir. Kasabalarda dügünlerin toplamda üç gün sürdüğü görülmektedir. Köylerdeki düğünlerle ilgili bilgi, geleneğin gücünü göstermesi bakımından ilginçtir. Ekonomik açıdan daha zor şartlarda yaşayan köylüler, kasabalılara göre daha fazla masraf etmekte, bazen haftalarca süren güreşler düzenlenmekte ve civar köyler ahalisi davet edilmektedir.

Halkın giyim konusu da monografide ele alınmıştır. Zenginler ve gençler setre pantolon; genç çiftçiler pantolon, yelek, mintan, aba, kuşak, fes, tülbent, tulumbacı yemenisi; esnaf kesiminin neredeyse tamamı setre pantolon, yelek kundura ve kısmen de potin; köylüler ise gaytanlı potur, salta, kuşak, çember, yemeni, kundura giymektedirler. Son zamanlarda köy gençlerinin bazıları şayaktan pantolon, setre, yelek; fakirler siyah bezden don, kuşak, keçe külah, çarık veya yemeni giymeye başlamışlardır. Hocalar dışında sarık saranlar nadirdir. Şehir kadınları oldukça muntazam siyah veya renkli çarşaf, iskarpin, modaya muvafik ceket ve entari, açık giysi ve kısa don; yaşlı kadınlar hâlihazırda eski usul giyiniyorsa da yeni yetişenlerin giysileri İstanbul kadınlarının kıyafetlerine yakındır. Muhacirler, kendi dokudukları yünden yapılma bürgü, uzunca don, gömlek yanında yerlilerin giysilerini de giymeye başlamışlardır. Köy kadınları adî basma veya dokumadan don, gömlek mintan, entari, adi kundura ve oyalı çember giymektedir (Türkiye'nin S1hhi-i İctimaî Coğrafyası Kırkkilisa "Kırklarili" Vilayeti, 1925: 23): "Köylerde ekseriya halk yalınayak gezerler. Köy kadınları Avrupa kumaş gibi şeylere özenmezler, bayram ve düğün zamanlarına ait olmak üzere Avrupa malı istimal ederler. Maalesef son zamanlarda yerli mallara rağbet gösterilmemekte ve Avrupa'nın süslü fakat kıymetsiz, çürük kumaşları yavaş yavaş köylere de sokulmaktadir."

\section{Sonuç}

Belirli bir zaman diliminde şehirlerin; toplumsal hayatın bütün cephelerinde dişa vurdukları koşullar ve özelliklerin, parçası oldukları devletin geçirdiği aşamaların izlerini yansıtmak yanında, bir kentin diğer şehirlerden ayrı cereyan etmiş tarihsel seyrinin sonuçlarını da barındırdıkları aşikârdır. Cumhuriyetin ilk yıllarında Kırklareli, tarıma dayalı iktisadî hayat, halkın günlük yaşamında gözlemlenebilen yoksulluğun/eğitimsizliğin eseri cehalet yönleriyle, yirminci yüzyıl başlarındaki Osmanlı toplumunun genel vasıflarını yansıtmaktadır. Ancak bu geri sosyalekonomik şartlara ağırlıklı olarak, yirminci yüz yllın ilk çeyreğinde Osmanlı'nın Rumeli coğrafyasında yaşanan siyasal gelişmeler ve Kırklareli'nin bu coğrafyada yer alan bir kent olması ile ilgilidir.

Yirminci yüzyıl başlarında Kırklareli, Türklerin yanında, ticarî faaliyetlerindeki başarılarıyla bilinen gruplar da dâhil, farklı etnik ve dinsel toplulukları barındıran, bağcılık, hayvancılık ve dokuma ürünlerini Avrupa pazarına satabilen bir kent idi. Balkan Savaşları, Birinci Dünya Savaş1 ve Yunan işgali ile kentin nüfus yapısı değişmiş, üretimde çöküş yaşanmıştır. Cumhuriyet’in ulusdevlet inşa etme politikaları hayata geçirilirken, savaşların sonuçları bağlamında Kırklareli'nde Türk nüfusu çoğunluk hâline gelmişti. Muhaceret Rumeli’nin gerçeğiydi ve bulaşıcı hastalıklar da yeni tarım ürünleri de muhacirlerce getirilmişti.

Osmanlı Devleti de cari olan geri kalmışlık koşullarının özellikle de anılan savaşların, Kırklareli halkının zihniyet ve çare arama yöntemlerine, birbirine zıt çaba ve eğilimler olarak yansıdığ1 görülmektedir. Sağlık sorunlarına türbelerde çare araması da, ayakta kalabilmek için eğitime dört elle sarılması da bu mealdedir. Cumhuriyetin ilk yıllarında iktisadî açıdan Kırklareli, birçok şehir gibi, yüksek potansiyeli, cılız sermaye sınıfı ile devletin planlı desteğine muhtaçtır. Cumhuriyetin temsil ettiği ve topluma benimsetmeye çalıştığ değerler açısından bakıldığında ise olumlulukların Kırklareli toplumunda daha geniş yer tuttuğu açıktır. Yüzyıllarca farklı dinsel ve etnik topluluklar, dolayısıyla farklı kültürler ile iç içe yaşamaktan gelen hoşgörü ve yeniliklere açık 
olma, Osmanlı eğitimindeki yenilikleri hızla benimseme, çaresizlikten kaynaklanan hurafelere karşlık kökleşmiş medrese zihniyetinin yokluğu, yoksulluğa rağmen gözlemlenebilen yaşama sevinci, şehir halkının Cumhuriyet'in prensip ve uygulamaları ile barışık olmasının temelini oluşturmuştur.

Günümüzde Kırklareli’nin ekonomik, sosyal ve kültürel yönleriyle taşıdığı nitelikleri 1925 yılı koşulları ve verileri ile karşılaştırmak; geçen zaman zarfinda Cumhuriyet'in ve kentin toplumsal kesimlerinin katkılarını değerlendirebilmek için bir zarurettir ki, başka bir yazının konusudur.

\section{Kaynakça}

1310 Senesine Mahsus Edirne Vilayeti Salnamesi (1894). Edirne: Vilayet Matbaas1.

AKIN, Veysi (1997). "Kırklareli Adının Tarihçesi”, Pamukkale Üniversitesi Eğitim Fakültesi Dergisi, (2): 9-12.

ARSLAN, Sezer (2008). Balkan Savaşları Sonrası Rumeli'den Türk Göçleri ve Osmanlı Devleti'nde İskânları, (Yayımlanmamış Yüksek Lisans Tezi), Trakya Üniversitesi Sosyal Bilimler Enstitüsü, Edirne.

AYSAL, Necdet ve Lütfi ARSLAN (2018). “Türkiye’nin Sağllk ve Toplumsal Coğrafyası: Cebel-i Bereket (Osmaniye) Vilâyeti”, Atatürk Yolu Dergisi, Ankara Üniversitesi Türk İnkilâp Tarihi Enstitüsü, (63): 419-451.

BAYER, Ertan (2020). "Hürfikir Gazetesi Kırklareli”. Erişim tarihi: 29/05/2020 http://www.hurfikir.com.tr/haber/7339/luleburgazin-bankasi-bile-vardi.html.

BORATAV, Pertev Naili (1973). 100 Soruda Türk Folkloru (Inanıslar, Töre ve Törenler, Oyunlar), İstanbul: Gerçek Yayınevi.

BURNAZ KABAKCI, Burcu (2013). XIX. Yüzyıl Ortalarında Kırklareli (Kırkkilise)'de Sosyal ve Ekonomik Hayat, (Yayımlanmamış Yüksek Lisans Tezi), İstanbul Üniversitesi Sosyal Bilimler Enstitüsü Tarih Anabilim Dalı, İstanbul.

DOĞRUÖZ, V. Türkan (2011). "Kırklareli Tarihine Işık Tutacak Bir Eser: Türkiye'nin Sıhhi-i İçtimaî Coğrafyası Kırklareli Vilayeti”, History Studies, 3(1): 275-284.

DOĞRUÖZ, V. Türkan (2005). Millî Mücadele'de Kırklareli, (Yayımlanmamış Doktora Tezi), İstanbul Üniversitesi Atatürk İlkeleri ve İnkılap Tarihi Enstitüsü Atatürk İlkeleri ve İnkılap Tarihi Anabilim Dalı, İstanbul.

Dr. Ahmed Hamdi (1341/1925). Türkiye'nin Sıbhi-i İctimai Coğrafyası Kırkeilisa "Kırklarili" Vilayeti, İstanbul: Kâğıtçılık ve Matbaacılık Anonim Şirketi.

Dr. Mehmet Said (1922). Türkiye'nin Sıbhi ve İctimai Coğrafyası: Sinop Sancağı, Türkiye Büyük Millet Meclisi Umur-1 Sıhhiye ve Muavenet-i İçtimaîye Vekâleti, Ankara: Öğüt Matbaası.

GÖKBAYRAK, Zeliha (2006). "Bağcillğın Belalı Zararlısı Filoksera", Alatarm, Alata Bahçe Kültürleri Araştırma Enstitüsü, 5(1): 37-43.

GÖKÇE, Nilifer- Mevlut YAPRAK (2012). “Türkiye’nin Sihhi ve İçtimaî Coğrafyası: Kırklareli Vilayeti Adlı Esere Göre Türkiye Cumhuriyeti'nin Kuruluşunda Kırklareli’nde Folklorik Tip", Lokman Hekim Journal, 2(1): 39-42.

GÜMÜŞÇÜ, Osman (1999). "Millî Mücadele Dönemi Türkiye Coğrafyası İçin Bilinmeyen Bir Kaynak: Türkiye'nin Sıhhi-İçtimaî Coğrafyası”, Atatürk. Araştırma Merkezị Dergisi, 15(45): 939968. 
GÜRAN, Tevfik (1997). Osmanl Dönemi Tarm Istatistikleri 1909, 1913 ve 1914, Tarihi İstatistikler Dizisi, Cilt 3, Ankara: T.C. Başbakanlık Devlet İstatistik Enstitüsü.

KANAL, Hümmet (2017). "İkinci Abdülhamit Döneminde Kırkkilise (Kırklareli) Sancağında Eğitim ve Öğretim”, OTAM, (41): 107-144. Yayınlar1.

KARPAT, Kemal (2010). Osmanl Nüfusu 1830-1914, çev. Bahar Tirnakçı, İstanbul: Timaş

KOZ, M Sabri (1992). "Türk Halk Kültürünün Unutulmuş Kaynaklarından Biri: “Türkiye'nin Sihhi-i İctimai Coğrafyası”, 4. Milletlerarası Türk Halk Kültürü Kongresi Bildirileri, Cilt I, ss. 37-58, Ankara: Feryal Matbaas1.

ÖZBEK, Ahmet (2018). Balkan Savaşlarında Kırklareli (Kırkkilise), (Yayımlanmamış Yüksek Lisans Tezi), Kırklareli Üniversitesi Sosyal Bilimler Enstitüsü Tarih Anabilim Dalı, Kurklareli.

SAYILIR, Burhan (2013). "Millî Mücadele Döneminde Batı Karadeniz'in (SinopKastamonu-Zonguldak) Sosyo-Kültürel ve Ekonomik Yapısı (Türkiye'nin Sıhhi İctimai Coğrafyası Raporlarına Göre)", Akademik Bakış Dergisi, (38): 1-20.

ŞEHSUVAROĞLU, Bedii Nuri ve Ayşegül DEMIRHAN ERDEMIR (1984). Türk T⿰дp Tarihi, Bursa: Taş Kitapçllık Yay. Ltd. Şti.

ŞİMŞEK, Hüseyin (2014). "Osmanlı Döneminde Kısa Süreli Öğretmen Yetiştirme Uygulamaları”, YYÜ Eğitim Fakültesi Dergisi, 11(I): 77-95.

TANILLI, Server (1976). Anayasalar ve Siyasal Belgeler, İstanbul: Cem Yayınevi.

TANÖR, Bülent (2002). Türkiye'de Kongre İktidarlar (1918-1920), İstanbul: Yap1 Kredi Yayınlar1.

TBMM Albümü 1920-2010 (2010). Ankara: TBMM Basın ve Halkla İlișkiler Müdürlüğü Yayınlar1.

TEKİR, Süleyman (2019). "Erken Cumhuriyet Dönemi Türkiye'de Bulaşıc1 Hastalıklarla Mücadele (1923-1930)", Türkiyat Arasttrmalan Enstitïsü Dergisi, (65): 407-430.

TOPRAK, Zafer (1995). Türkiye'de Ekonomi ve Toplum (1908-1950) Milli İktisat-Milli Burjuvąi, İstanbul: Tarih Vakfi Yurt Yayınları.

TUNAYA, Tark Zafer (1989). Türkiye'de Siyasal Partiler, Ittihat ve Terakki Bir Cağın, Bir Kusağın, Bir Partinin Taribi, Cilt III, İstanbul: Hürriyet Vakfi Yayınları.

Türkşe Sözlïk, Dil Derneği Yayınları, Ankara 2005.

Türkiye'de Sibhat ve İ̧timai Muavenet Teşkilatmm Cumburiyet Devrindeki İnkişafı (1937). Ankara: Yayınevi Yok.

UZUNÇARŞILI, İsmail Hakkı (1994). Osmank Taribi, Cilt I, Ankara: TTKK Yayınları.

YAVUZ, Erdem (2018). "Sihhat ve İçtimâ̂ Muavenet Vekâletinin 1924 Y1lı Sitma İle Mücadele Raporu - Sitma ve Bataklık Haritası" Journal of Social and Humanities Sciences Research, 5(19): 639-653.

YILDIRIM, Seyfi (2012). "Balkan Savaşları ve Sonrasındaki Göçlerin Türkiye Nüfusuna Etkileri”, Cumburiyet Taribi Arastırmalar Dergisi, 8(16): 75-92.

Yurt Ansiklopedisi, Türkiye, Il İl: Dünü, Bugünü, Yarm, Cilt 7, Anadolu Yayıncilık, İstanbul 1983. 
AYSAL, Necdet ve Hasan DİNÇER (2020). “Türkiye'nin Sıłhhî ve İçtimaî Coğrafyası Raporlarına Göre:

Kirklareli”, Mavi Atlas, 8(2): 235-255

\section{Ekler}

Ek-1

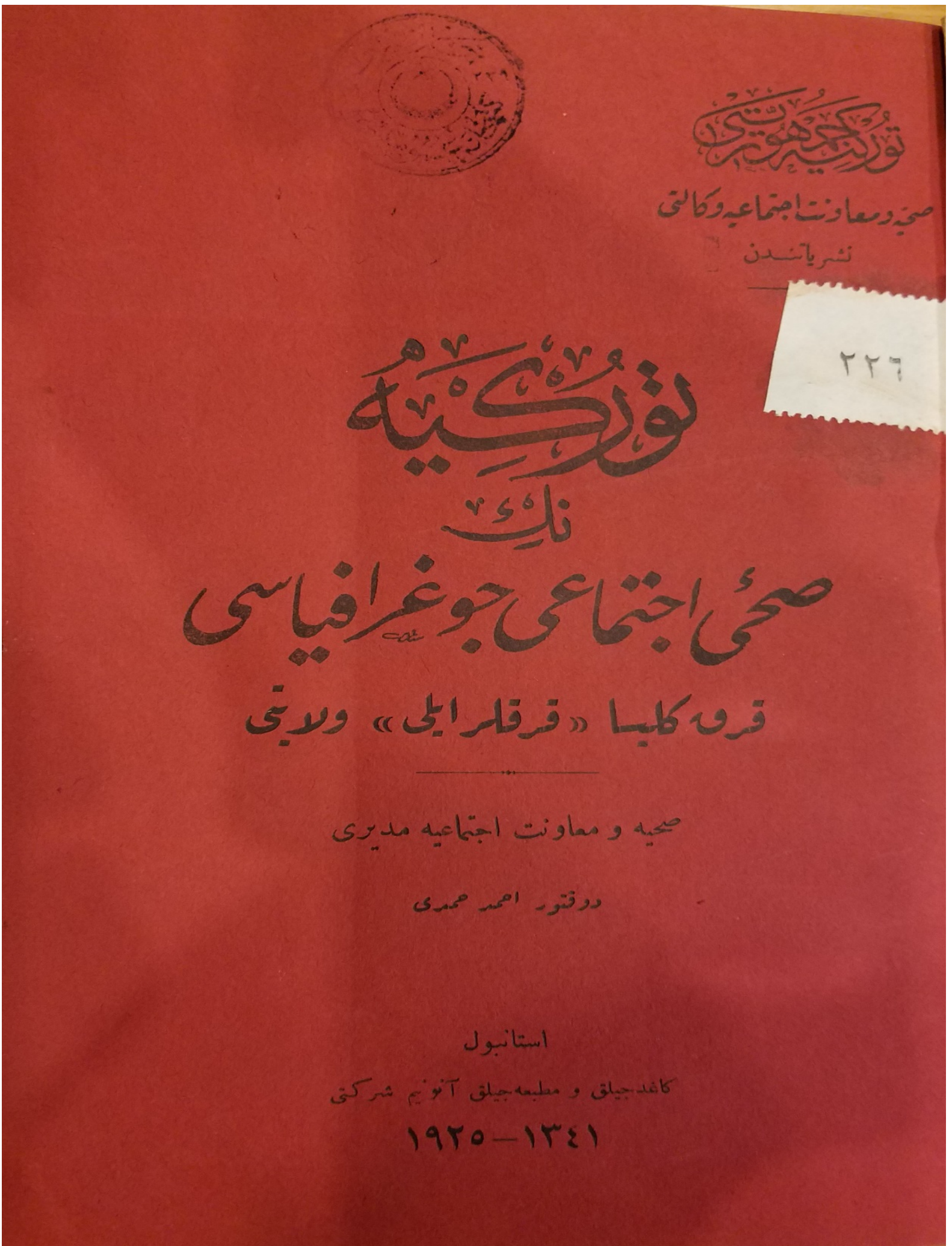

Türkiye’nin Sıhhi-i İctimai Coğrafyası Kırkkilisa "Kırklarili” Vilayeti (1925). (Haz. Dr. Ahmed Hamdi), İstanbul: Kâğıtçılık ve Matbaacıllı Anonim Şirketi. 


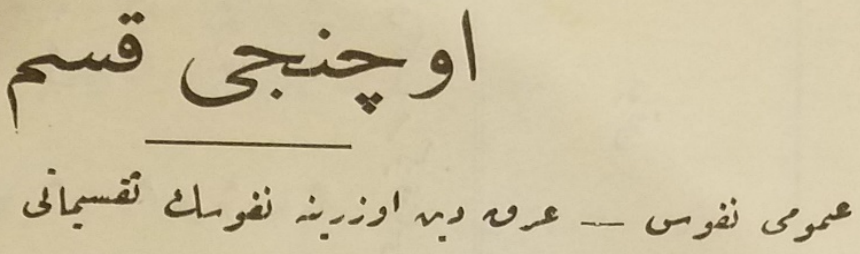

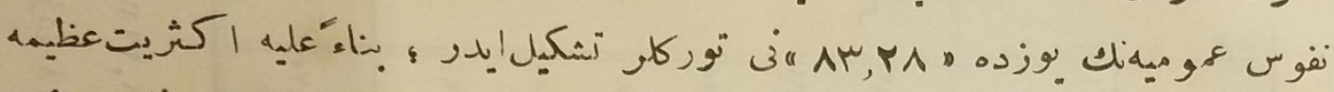

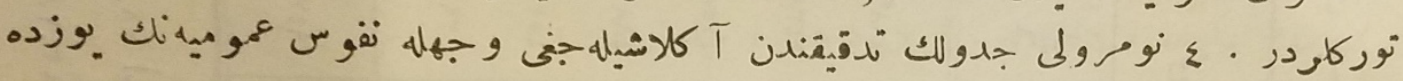

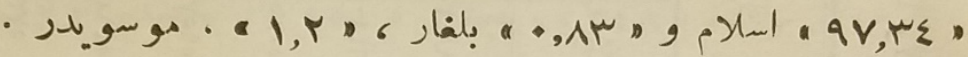

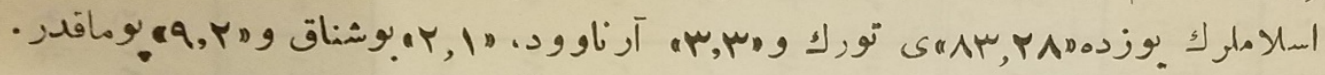

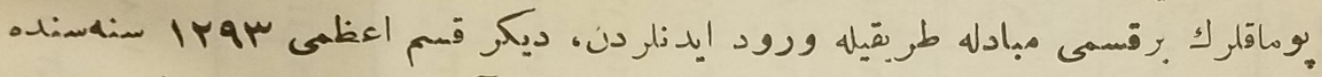

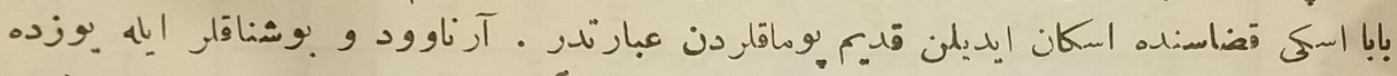

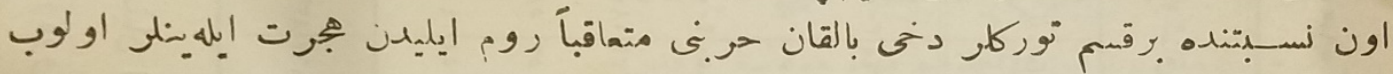

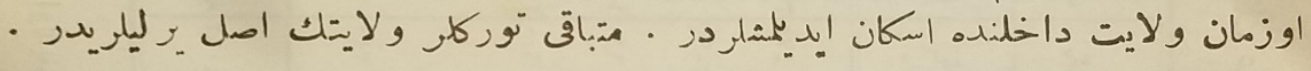
عنـا

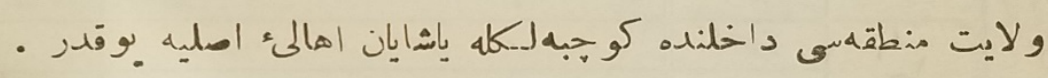
لساش عمومى

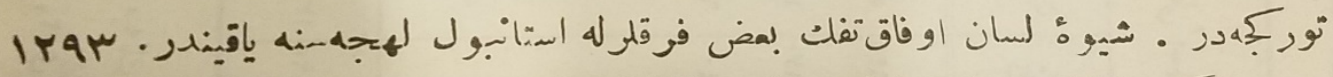

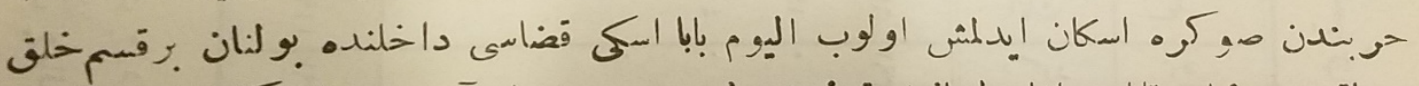

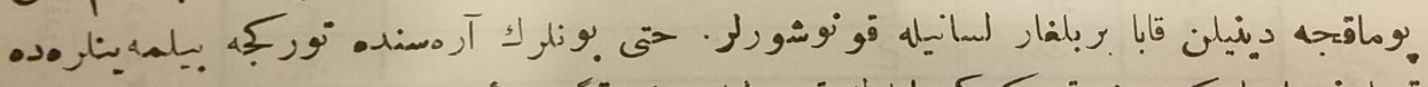

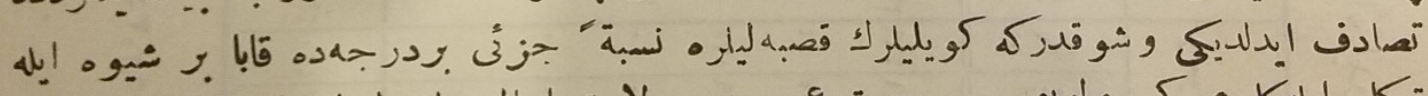

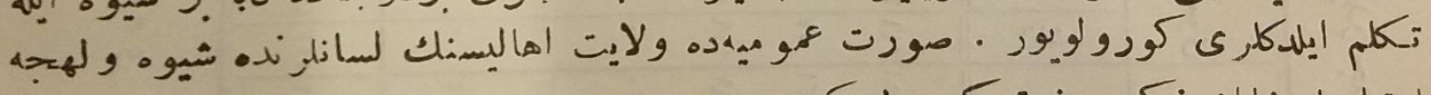

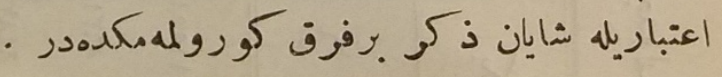

$$
\text { طر: تلبسى }
$$

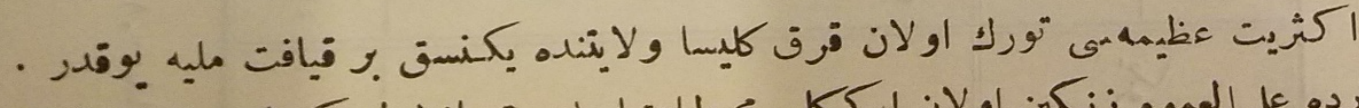

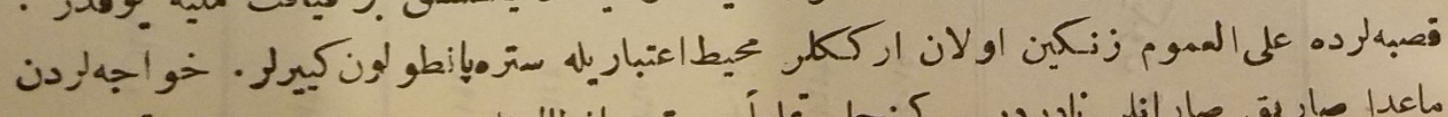

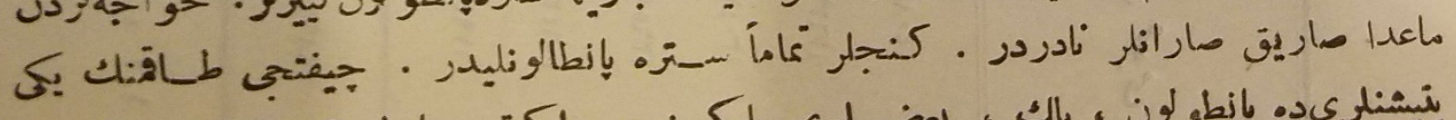

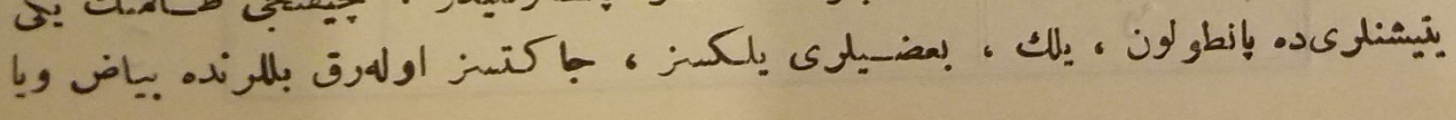

Türkiye'nin Sıhhi-i İctimai Coğrafyası Kırkkilisa “Kırklarili” Vilayeti (1925). (Haz. Dr. Ahmed Hamdi), s. 20, İstanbul: Kâğgtçılık ve Matbaacılık Anonim Şirketi. 


\section{- rq -}

و يزهده آثار عتيقهدن غايت هتين . وحام هو جود اولوب ياقين زمانه قادار ايشلهدملكده.

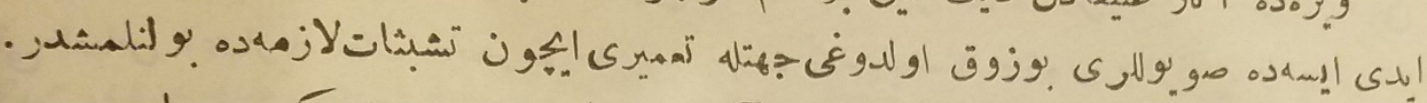

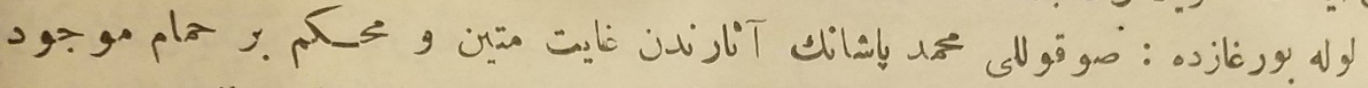

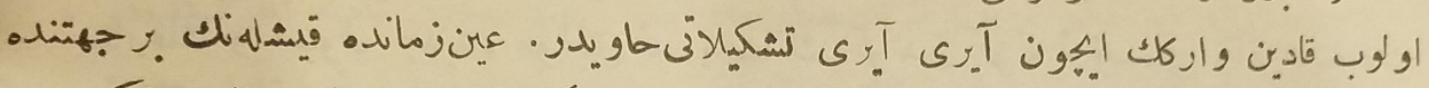

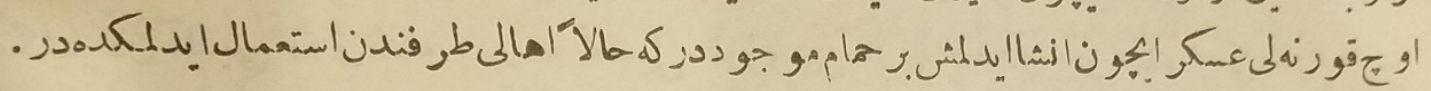

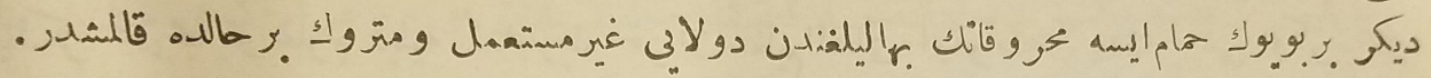
•.

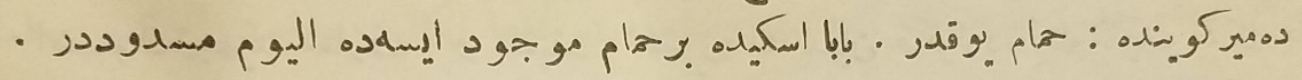

$$
\text { فإ-بقـ }
$$

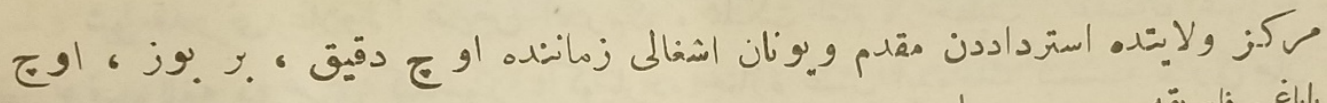

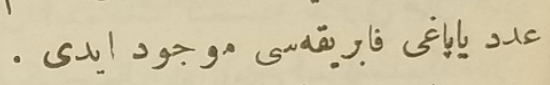

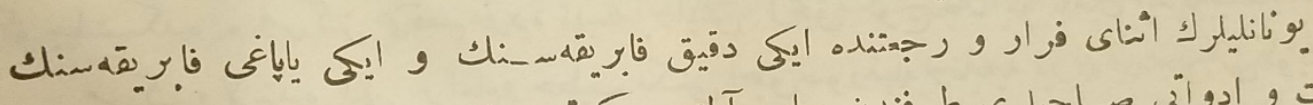

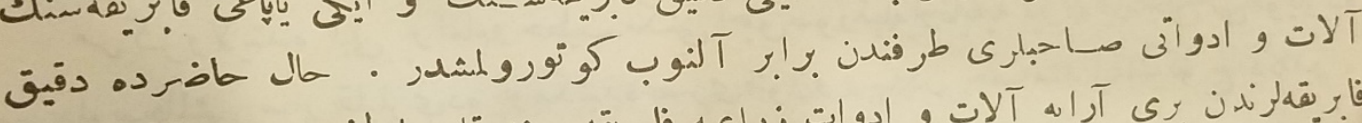

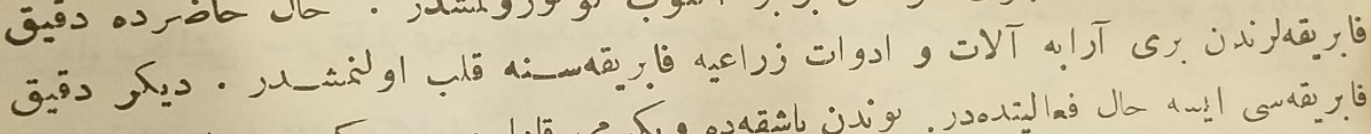

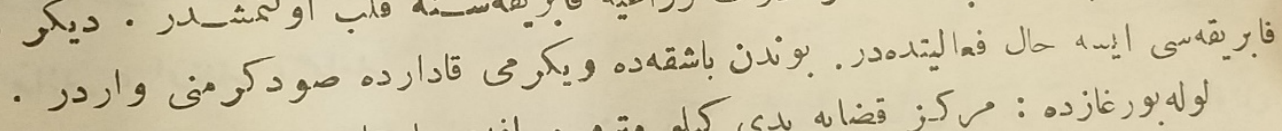

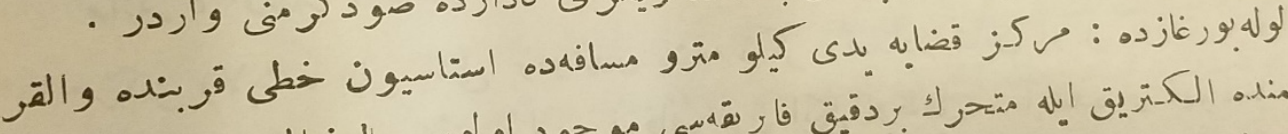

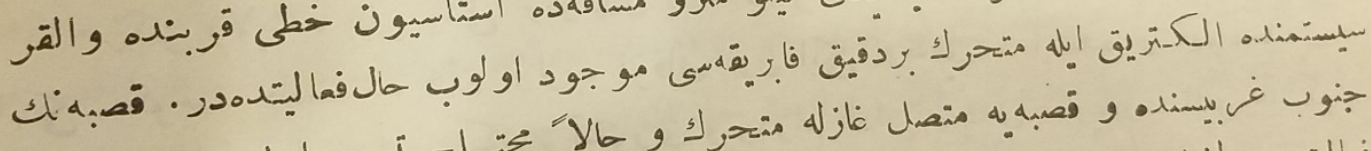

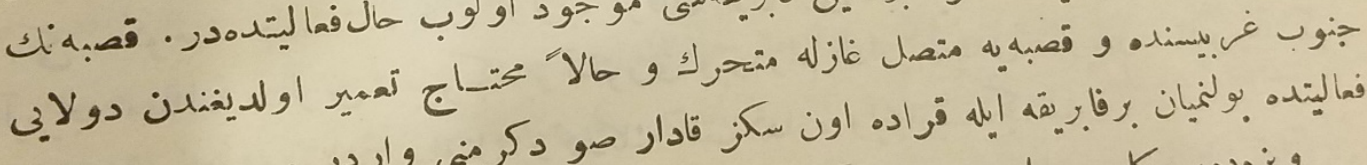

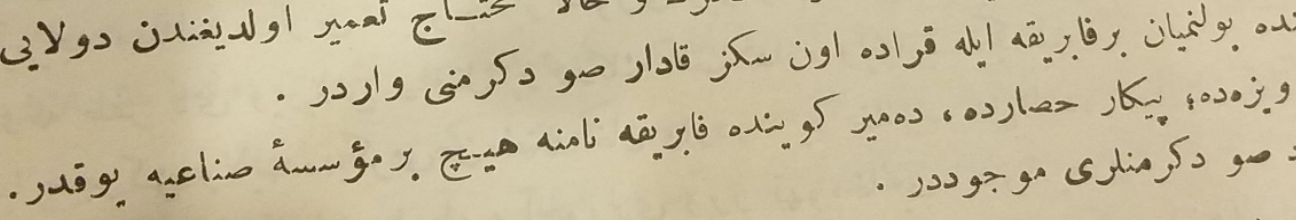

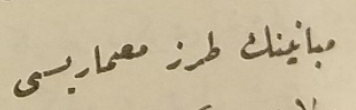

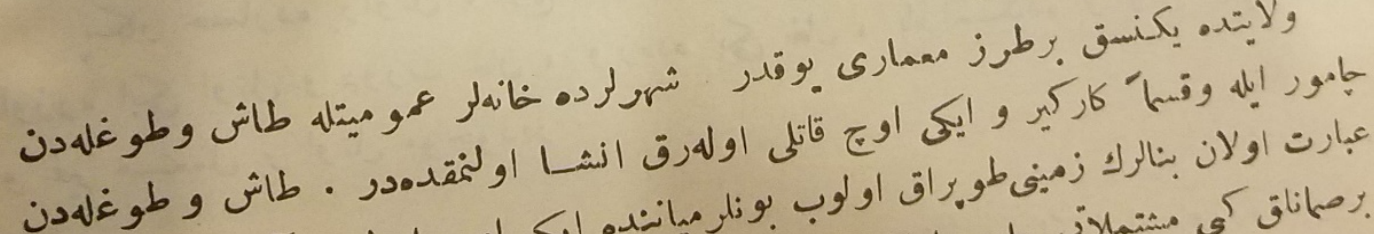

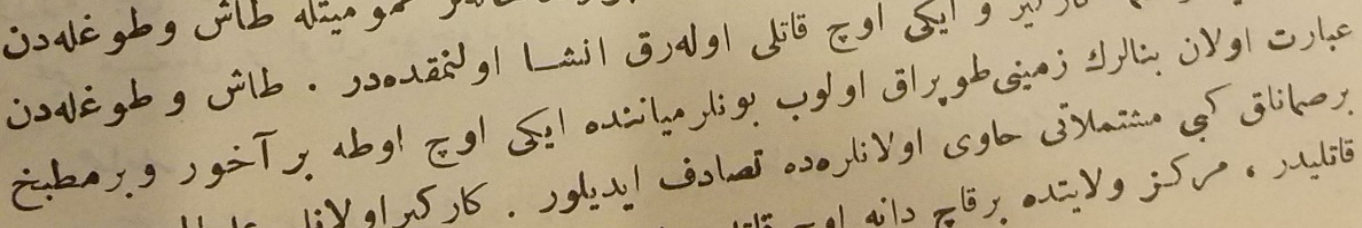

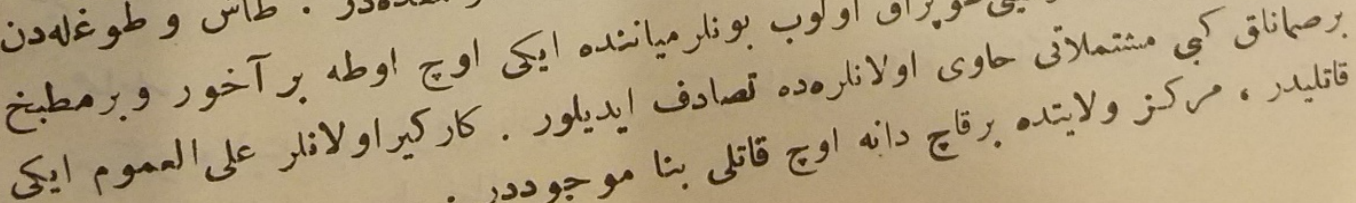

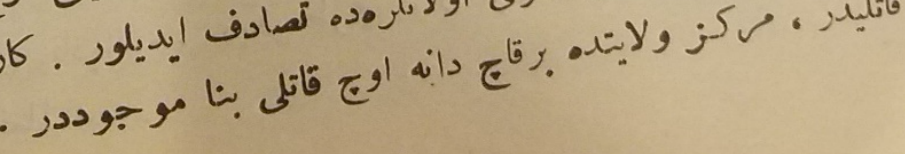

Türkiye’nin Sıhhi-i İctimai Coğrafyası Kırkkilisa "Kırklarili” Vilayeti (1925). (Haz. Dr. Ahmed Hamdi), s. 36, İstanbul: Kâğıtçlık ve Matbaacılık Anonim Şirketi. 


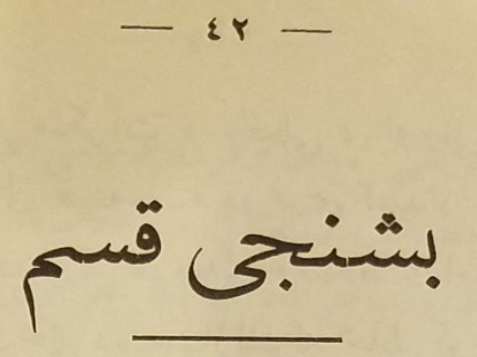

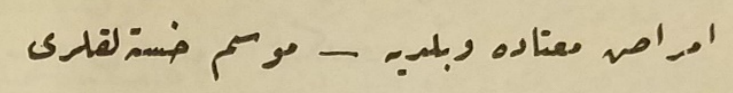

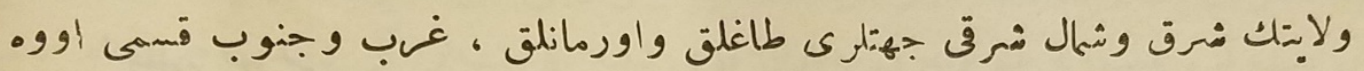

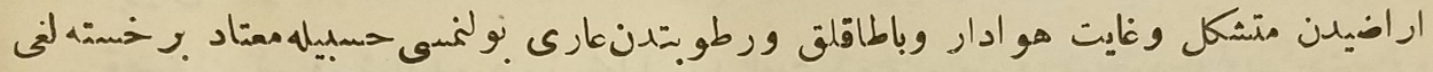

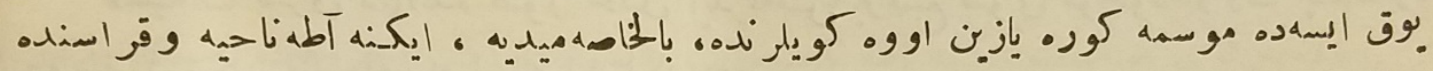

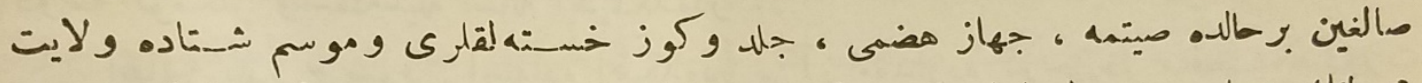

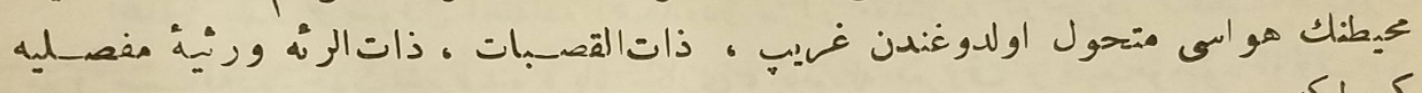
كورلمـدمدر

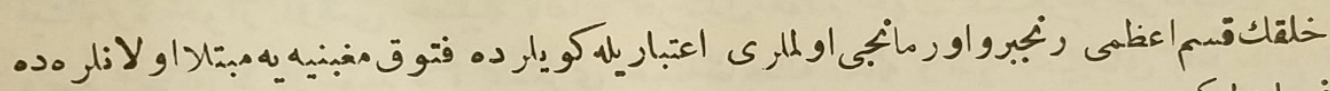
• تصادف إبلميكدهدر اعظى زفمكى و فحسى

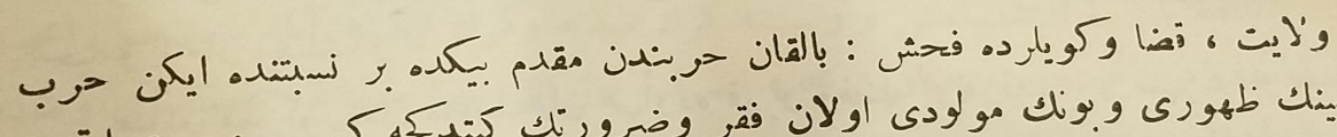

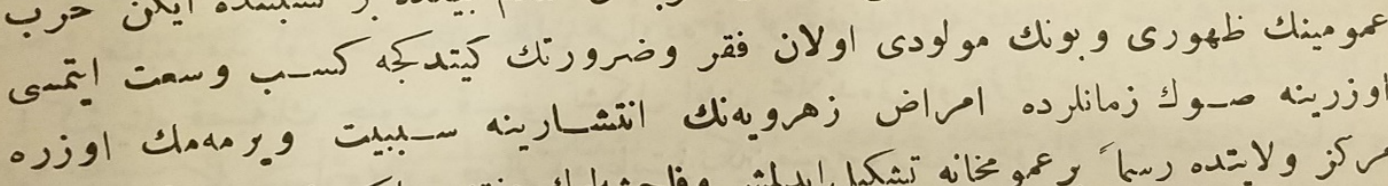

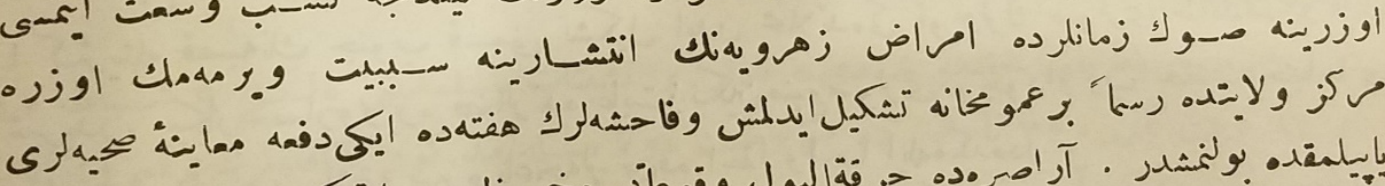

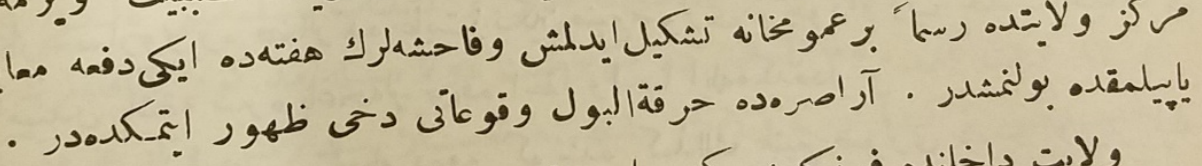

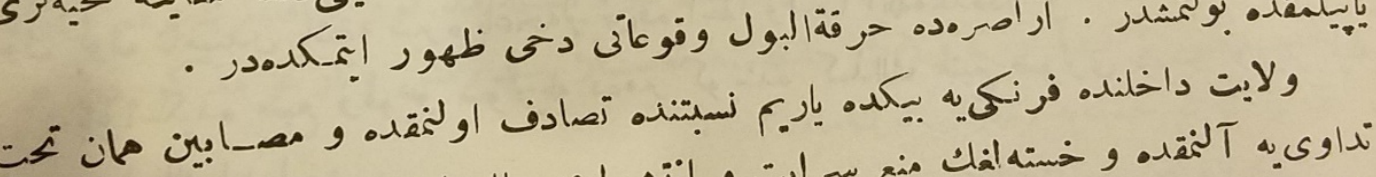

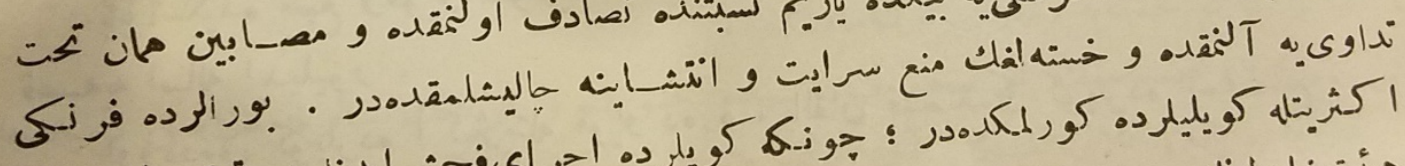

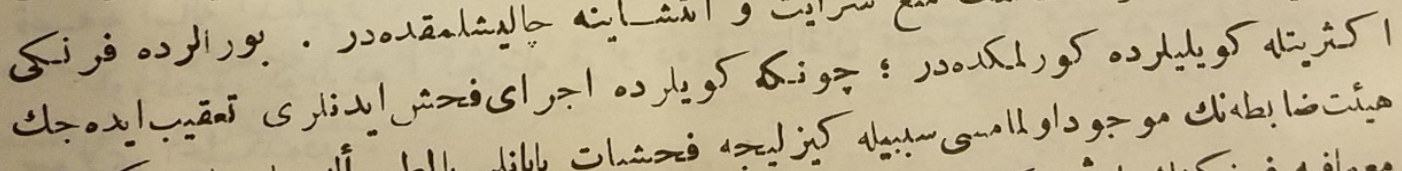

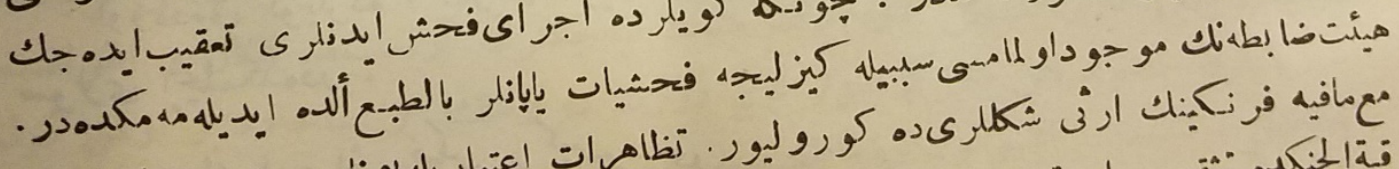

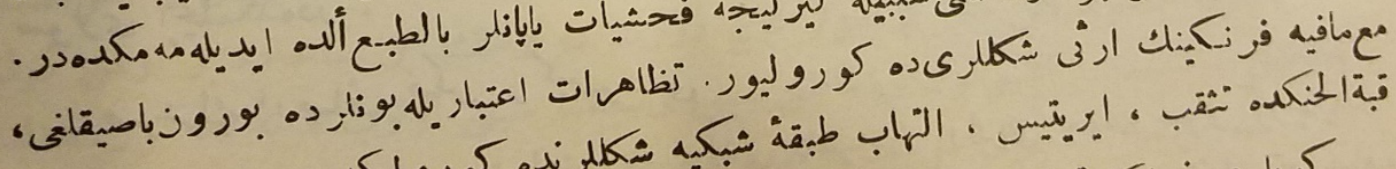

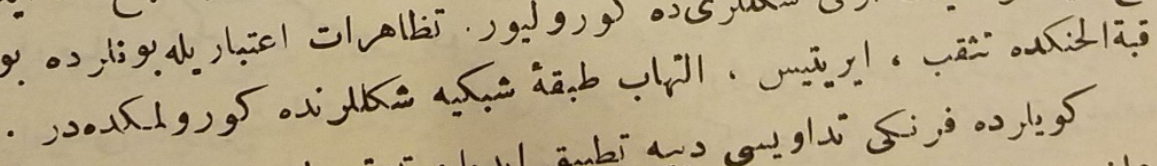

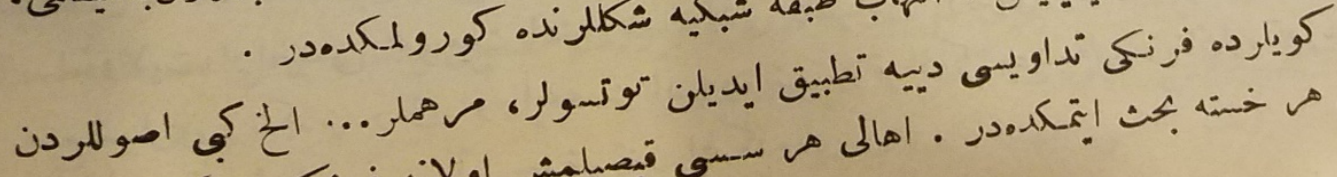

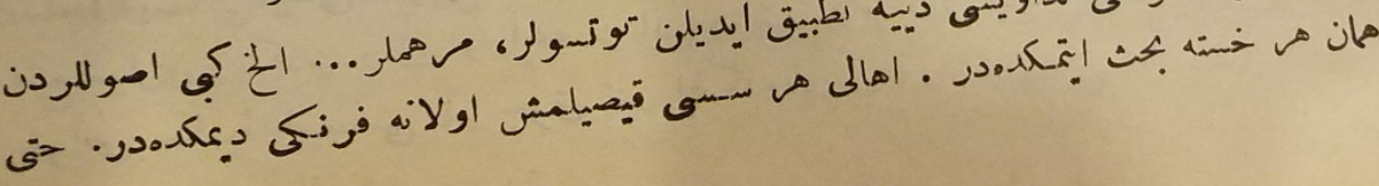

Türkiye'nin Sıhhi-i İctimai Coğrafyası Kırkkilisa “Kırklarili” Vilayeti (1925). (Haz. Dr. Ahmed Hamdi), s. 42, İstanbul: Kâğıtçlık ve Matbaacılık Anonim Şirketi. 
AYSAL, Necdet ve Hasan DİNÇER (2020). “Türkiye'nin Sıłhhî ve İçtimaî Coğrafyası Raporlarına Göre:

Kirklareli”, Mavi Atlas, 8(2): 235-255

\section{Ek-5}

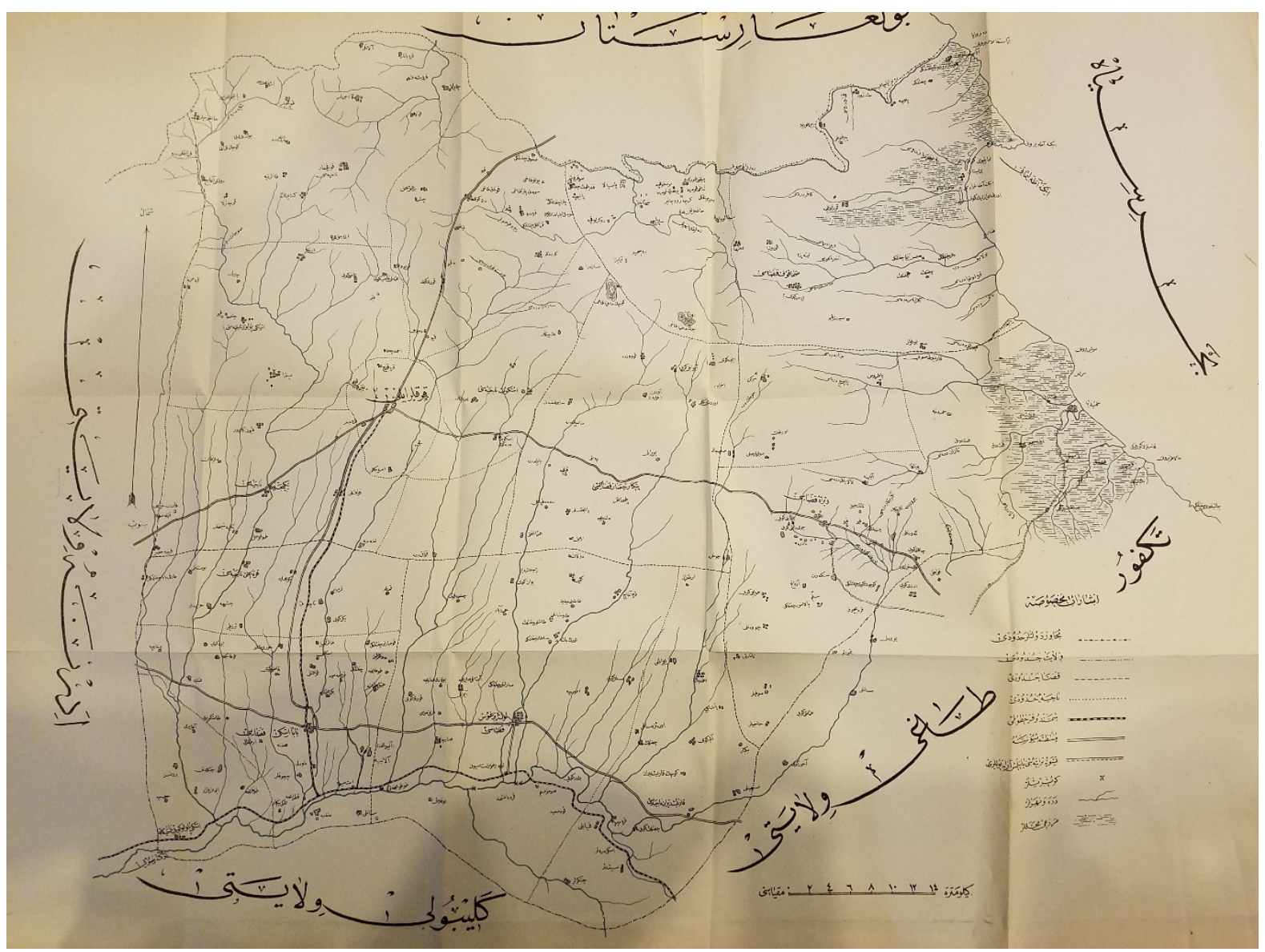

Türkiye'nin Sıhhi-i İctimai Coğrafyası Kırkkilisa "Kırklarili” Vilayeti (1925). (Haz. Dr. Ahmed Hamdi), s. 45, İstanbul: Kâğ 1 tçılık ve Matbaacılık Anonim Şirketi. 